\title{
Organ-specific expression of IGF-I during early development of bony fish as revealed in the tilapia, Oreochromis niloticus, by in situ hybridization and immunohistochemistry: indication for the particular importance of local IGF-I
}

\author{
Berishvili, G ; Shved, N ; Eppler, E ; Clota, F ; Baroiller, J F ; Reinecke, M
}

\begin{abstract}
The cellular sites of insulin-like growth factor I (IGF-I) synthesis in the early developing tilapia (0-140 days post fertilization, DPF) were investigated. IGF-I mRNA and peptide appeared in liver as early as 4 DPF and in gastro-intestinal epithelial cells between 5-9 DPF. In exocrine pancreas, the expression of IGF-I started at 4 DPF and continued until 90 DPF. IGF-I production was detected in islets at $6 \mathrm{DPF}$ in non-insulin cells and occurred throughout life. In renal tubules and ducts, IGFI production started at $8 \mathrm{DPF}$. IGF-I production in chondrocytes had its onset at 4 DPF, was more pronounced in growing regions and was also found in adults. IGF-I mRNA and peptide appeared in the cytoplasm of skeletal muscle cells at 4 DPF. In gill chloride cells, IGF-I production started at 6 DPF. At 13 DPF, IGF-I was detected in cardiac myocytes. IGF-I-producing epidermal cells appeared at 5 DPF. In brain and ganglia, IGF-I was expressed in virtually all neurones from 6 to $29 \mathrm{DPF}$, their number decreasing with age. Neurosecretory IGF-I-immunoreactive axons were first seen in the neurohypophysis around 17 DPF. Endocrine cells of the adenohypophysis exhibited IGF-I mRNA at 28 DPF and IGF-I immunoreactivity at 40 DPF. Thus, IGF-I appeared early (4-5 DPF), first in liver, the main source of endocrine IGF-I, and then in organs involved in growth or metabolism. The expression of IGF-I was more pronounced during development than in juvenile and adult life. Local IGF-I therefore seems to have a high functional impact in early growth, metabolism and organogenesis.
\end{abstract}

DOI: https://doi.org/10.1007/s00441-005-0133-9

Posted at the Zurich Open Repository and Archive, University of Zurich

ZORA URL: https://doi.org/10.5167/uzh-29958

Journal Article

Published Version

Originally published at:

Berishvili, G; Shved, N; Eppler, E; Clota, F; Baroiller, J F; Reinecke, M (2006). Organ-specific expression of IGF-I during early development of bony fish as revealed in the tilapia, Oreochromis niloticus, by in situ hybridization and immunohistochemistry: indication for the particular importance of local IGF-I. Cell and Tissue Research, 325(2):287-301.

DOI: https://doi.org/10.1007/s00441-005-0133-9 


\section{Organ-specific expression of IGF-I during early development of bony fish as revealed in the tilapia, Oreochromis niloticus, by in situ hybridization and immunohistochemistry: indication for the particular importance of local IGF-I}

Received: 8 September 2005 / Accepted: 23 November 2005 / Published online: 5 April 2006

(C) Springer-Verlag 2006

\begin{abstract}
The cellular sites of insulin-like growth factor I (IGF-I) synthesis in the early developing tilapia (0-140 days post fertilization, DPF) were investigated. IGF-I mRNA and peptide appeared in liver as early as 4 DPF and in gastro-intestinal epithelial cells between 5-9 DPF. In exocrine pancreas, the expression of IGF-I started at 4 DPF and continued until 90 DPF. IGF-I production was detected in islets at 6 DPF in non-insulin cells and occurred throughout life. In renal tubules and ducts, IGF-I production started at $8 \mathrm{DPF}$. IGF-I production in chondrocytes had its onset at $4 \mathrm{DPF}$, was more pronounced in growing regions and was also found in adults. IGF-I mRNA and peptide appeared in the cytoplasm of skeletal muscle cells at 4 DPF. In gill chloride cells, IGF-I production started at 6 DPF. At 13 DPF, IGF-I was detected in cardiac myocytes. IGF-I-producing epidermal cells appeared at 5 DPF. In brain and ganglia, IGF-I was expressed in virtually all neurones from 6 to $29 \mathrm{DPF}$, their number decreasing with age. Neurosecretory IGF-I-immunoreactive axons were first seen in the neurohypophysis around 17 DPF. Endocrine cells of the adenohypophysis exhibited IGF-I mRNA at $28 \mathrm{DPF}$ and IGF-I immunoreactivity at $40 \mathrm{DPF}$. Thus, IGF-I appeared early (4-5 DPF), first in liver, the main source of endocrine IGF-I, and then in organs involved in growth or metabolism. The expression of IGF-I was more
\end{abstract}

This study was supported by the SNF (NRP 50, project 405066580).

F. Clota $\cdot$ J.-F. Baroiller

CIRAD, UPR20 Aquaculture,

Montpellier, France

G. Berishvili · N. Shved · E. Eppler · M. Reinecke $(\triangle)$

Division of Neuroendocrinology, Institute of Anatomy,

University of Zürich,

Zürich, Switzerland

e-mail: reinecke@anatom.unizh.ch

Tel.: +41-44-6355370

Fax: +41-44-6355702 pronounced during development than in juvenile and adult life. Local IGF-I therefore seems to have a high functional impact in early growth, metabolism and organogenesis.

Keywords Liver - Gastro-intestinal tract - Pancreas . Kidney · Muscle · Brain · Pituitary · Gills · Heart · Epidermis · Tilapia

\section{Introduction}

Autocrine, paracrine and endocrine signals co-ordinate the direction of differentiation of tissues during critical periods of development. The differentiation of organs thus involves a complex cascade and interaction of signals whose organizational action on tissue differentiation is dependent on being released at precise times, at correct sites (in the case of para- and autocrine factors) and within a specific dose range (Segner et al. 1994). Insulin-like growth factor I (IGF-I) plays a central role in the complex system that regulates growth, differentiation and reproduction (see review: Reinecke and Collet 1998).

As in mammals, the major site of IGF-I gene expression in bony fish is liver but several extrahepatic sites also express IGF-I (for reviews, see Reinecke and Collet 1998; Duan 1998; Reinecke et al. 2005; Wood et al. 2005). Recently, by the use of real-time reverse transcription/ polymerase chain reaction (RT-PCR), the absolute amounts of IGF-I have been measured in adult tilapia, Oreochromis niloticus (Caelers et al. 2004), and significant levels of IGF-I mRNA have been measured not only in liver, but also in other organs, such as brain, gills, heart, intestine, kidney, skeletal muscle, spleen and testes. These results are consistent with the earlier immunohistochemical identification of parenchymal cells as local production sites in numerous organs of tilapia (Reinecke et al. 1997) and indicate paracrine/autocrine actions of local IGF-I involved in organ-specific functions of adult bony fish.

Some studies in bony fish showing the presence of IGF-I and its receptor (IGF-1R) in fish embryos suggest a high 
organizational impact of IGF-I during ontogeny. Developmental and tissue-specific regulation of the steady-state mRNA levels of IGF-1R and polyadenylation have been detected in rainbow trout (Greene and Chen 1999) and seabream (Perrot et al. 1999). Correspondingly, some RTPCR studies on trout (Shamblott and Chen 1993; Duan et al. 1995; Greene and Chen 1997, 1999), seabream (Duguay et al. 1996; Perrot et al. 1999) and rabbitfish (Ayson et al. 2002) suggest that the expression patterns of IGF-I mRNA in several organs are also age-dependent. The physiological importance of IGF-I in early fish development is further underlined by the demonstration of the marked mitogenic effects of IGF-I on zebrafish embryonic cells (Pozios et al. 2001).

However, little information exists regarding the cellular sites of IGF-I synthesis, with only two studies in seabream (Perrot et al. 1999) and rabbitfish (Radaelli et al. 2003) and some preliminary data in tilapia (Shved et al. 2005) reporting the localization of IGF-I during ontogeny. These reports involve the investigation of several organs at different larval stages by the use of immunohistochemistry. However, no thorough study on the cellular IGF-I production during early fish development has been performed and no other species have been examined. Furthermore, to date, in situ hybridization has not been used to detect the cellular expression of IGF-I mRNA during ontogeny. Therefore, we have investigated the potential production sites of IGF-I in numerous organs, such as liver, gastro-intestinal tract, exo- and endocrine pancreas, kidney, skeletal muscle, cartilage, gills, skin, brain and pituitary, in early developmental stages, i.e. from 0 day post fertilization (DPF) to $140 \mathrm{DPF}$, of tilapia (Oreochromis niloticus) and in adult individuals. We have used immunohistochemistry to localize IGF-I peptide and in situ hybridization to detect the expression of IGF-I mRNA.

\section{Materials and methods}

\section{Animals}

The fry and adult Oreochromis niloticus used in this study originated from the Aquaculture Experimental Facilities of CIRAD (Montpellier). Fertilized eggs were obtained through either natural or artificial fertilization. For natural fertilization, 0. niloticus breeders (1 male and 3 females) were maintained in a spawning aquarium of 3601 maintained at constant temperature $\left(27^{\circ} \mathrm{C}\right)$ and photoperiod (12L:12D). Under natural photoperiods, reproductive activity occurs mainly from the afternoon until sunset in these species (Baroiller et al. 1997). Consequently, we checked every morning for the presence of newly incubating females, which were then isolated from the other fish. On the first day after fertilization, eggs were gently removed from the mouth of the female and incubated in 1-1 McDonald jars at $27 \pm 1^{\circ} \mathrm{C}$ (mean range). For artificial fertilization, the maturation of isolated females was carefully recorded (i.e. uro-genital papilla development and behaviour). When the near-breeding stage was reached, both male and female breeders were striped under anaesthesia. Fertilization was performed according to Chourrout and Itskovitch (1983). After fertilization, eggs were incubated in 1-1 McDonald jars, maintained at $27^{\circ} \mathrm{C}$, to the free-swimming stage (around $10 \mathrm{DPF}$ ). Just before the completion of yolk sac absorption, fry were placed into a 50-1 tank in an indoor recirculating system at $27 \pm 1^{\circ} \mathrm{C}$. They were fed with commercial salmonid food.

Fish larvae at various developmental stages, i.e. from 0-140 DPF, and adults were sampled and anaesthetized by the addition of 2-phenoxy-ethanol (Sigma, St. Louis, Mo., USA) to water $(0.3 \mathrm{ml} / \mathrm{l})$. For the earliest stages, the trunk was cut to allow fixation solution to enter. If the larvae had reached a sufficient size, the organs were excised. Tissue preparations were fixed with Bouin's solution without acetic acid for $4 \mathrm{~h}$ at room temperature. Specimens were dehydrated in an ascending series of ethanol and routinely embedded in Paraplast $\left(58^{\circ} \mathrm{C}\right)$.

Generation of tilapia-specific probes for in situ hybridization

The probes used were prepared as previously described (Schmid et al. 1999). In brief, total RNA from tilapia liver was extracted by the phenol/chloroform method with an Ultraspec Extraction Kit (ams, Lugano, Switzerland). For cDNA synthesis, $5 \mu \mathrm{g}$ RNA were annealed with $1 \mu \mathrm{M}$ poly (dT) primer (5'-CC TGAATTCTAGAGCTCAT(dT17)-3') for $3 \mathrm{~min}$ at $70^{\circ} \mathrm{C}$. The RNA/primer mix was incubated for $1 \mathrm{~h}$ at $37^{\circ} \mathrm{C}$ with $15 \mathrm{mM}$ dNTPs and $10 \mathrm{U}$ AMV-reverse transcriptase (Pharmacia, Switzerland) in $1 \times$ reaction buffer $(50 \mathrm{mM}$ TRIS-HCl pH 8.3, $40 \mathrm{mM} \mathrm{KCl}, 6 \mathrm{mM}$ $\mathrm{MgCl}_{2}$ ). A $1-\mu \mathrm{l}$ cDNA aliquot was incubated with $1 \mu \mathrm{M}$ of the sense (5'-GTCTGTGGAGAGCGAGGCTTT-3') and antisense primer (5'-AACCTTGGGTGCTCTTGGCATG$3^{\prime}$ ), corresponding to the B- and E- domains (Reinecke et al. 1997), $200 \mu \mathrm{M}$ dNTPs, and 1 U Taq-polymerase (Pharmacia) in $1 \times$ incubation buffer $(10 \mathrm{mM}$ TRIS-HCl $\mathrm{pH}$ $8,50 \mathrm{mM} \mathrm{KCl}, 1.5 \mathrm{mM} \mathrm{MgCl} 2,0.001 \%$ gelatine). The amplification program was optimized for a Stratagene RoboCycler Gradient 40 as follows: one cycle of $10 \mathrm{~min}$ at $94^{\circ} \mathrm{C}, \quad 1 \mathrm{~min}$ at $59^{\circ} \mathrm{C}, 2 \mathrm{~min}$ at $72^{\circ} \mathrm{C} ; 30$ cycles of $1 \mathrm{~min}$ at $94^{\circ} \mathrm{C}, 1 \mathrm{~min}$ at $59^{\circ} \mathrm{C}$ and $2 \mathrm{~min}$ at $72^{\circ} \mathrm{C}$ followed by a final extension step of $5 \mathrm{~min}$ at $72^{\circ} \mathrm{C}$. PCR fragments were separated on a $2 \%$ agarose gel and eluted by Gel Extraction Kit QIAquick (Qiagen, Switzerland). PCR products were cloned in a pCR-Script $\mathrm{SK}(+)$ cloning vector (Stratagene, Heidelberg, Germany). After propagation of Escherichia coli containing the plasmids, purification of the plasmids was performed with the Midi Purification Kit (Qiagen). Plasmids with the IGF-I fragment were sequenced (Microsynth, Switzerland) and the sequences were compared with those in a database. The plasmids containing the specific inserts of IGF-I (207 bp) were used as templates for the synthesis of the digoxigenin (DIG)-labelled RNA probes. Linearization was performed with the restriction enzyme EcoRI for T3 polymerase-driven transcription and with 
NotI for T7 polymerase-driven transcription. After ethanol precipitation, linearization efficiency was assured on a $1.2 \%$ agarose gel. The linearized plasmids $(1 \mu \mathrm{g})$ were transcribed in vitro by using a transcription kit (Roche Diagnostics, Germany) in the presence of DIG-UTP to obtain the antisense and sense probes. The IGF-I probes selectively detected tilapia IGF-I and not tilapia IGF-II, as shown previously (Schmid et al. 1999). The integrity of the probes and the efficiency of the labelling were confirmed by gel electrophoresis, including blotting and incubation with antibody $(\mathrm{Ab})$, and by dot blot. For dot blot, $1 \mu \mathrm{l}$ various dilutions (undiluted, 1:10, 1:100, 1:1,000) of probes and control RNAs were dropped onto a nylon membrane (Roche Diagnostics) and fixed by UV crosslinking (254 nm, $125 \mathrm{~mJ})$. The membrane was washed with $1 \%$ blocking reagent (Roche-Diagnostics) in buffer P1 for 30 min followed by treatment with alkaline phosphatase (AP)-coupled anti-DIG Ab (Roche Diagnostics) diluted at $1: 2,000$ with $1 \%$ blocking reagent in $\mathrm{P} 1$ for $30 \mathrm{~min}$. After a rinse with $\mathrm{P} 1$, the membrane was equilibrated with buffer P3 and finally washed with 1:50 diluted nitroblue tetrazolium/5-bromo-4-chloro-3-indolyl-phosphate (NBT/BCIP) stock solution (Roche Diagnostics) until colour develop- ment. For gel electrophoresis and blotting, probes (200 ng) were loaded onto a $1 \%$ denaturing formaldehyde agarose gel in $1 \times$ MOPS and run at $80 \mathrm{~V}$ for $1.5 \mathrm{~h}$. After the run, gel and membrane were shaken in diethylpyrocarbonate (DEPC) $-\mathrm{H}_{2} \mathrm{O}$ for $5 \mathrm{~min}$. Capillary transfer was carried out with $20 \times$ standard sodium citrate (SSC) overnight. Nucleic acids were fixed by UV-crosslinking. Subsequently, the membrane was incubated with the AP-labelled anti-DIG $\mathrm{Ab}$ by applying the same procedure as for dot blot. Lengths of the probes were compared with control RNA (760 nt, Roche Diagnostics).

In situ hybridization protocol

Sections ( $4 \mu \mathrm{m}$ thick) were mounted on Super Frost Plus slides (Menzel-Gläser, Germany) and dried overnight at $42^{\circ} \mathrm{C}$. After being dewaxed and rehydrated, the sections were fixed with $4 \%$ paraformaldehyde and $0.1 \%$ glutaraldehyde in $1 \times$ phosphate-buffered saline (PBS). The following steps were carried out with DEPC-treated solutions in a humified chamber. The sections were digested with $0.02 \%$ proteinase $\mathrm{K}$ in $20 \mathrm{mM}$ TRIS-HCl

Table 1 Semiquantitative grading of the number of parenchymal cells demonstrated by IGF-I in situ hybridization (ISH) and IGF-I immunohistochemistry (IHC)

\begin{tabular}{|c|c|c|c|c|c|c|c|c|c|c|c|c|c|c|c|c|c|c|c|c|}
\hline \multirow[t]{2}{*}{ Organ } & \multicolumn{2}{|l|}{$\begin{array}{l}\text { DPF } \\
4-5\end{array}$} & \multicolumn{2}{|l|}{$\begin{array}{l}\text { DPF } \\
6-7 \\
\end{array}$} & \multicolumn{2}{|c|}{$\begin{array}{l}\text { DPF } \\
8-12\end{array}$} & \multicolumn{2}{|c|}{$\begin{array}{l}\mathrm{DPF} \\
13-18 \\
\end{array}$} & \multicolumn{2}{|c|}{$\begin{array}{l}\text { DPF } \\
19-29 \\
\end{array}$} & \multicolumn{2}{|c|}{$\begin{array}{l}\text { DPF } \\
30-50\end{array}$} & \multicolumn{2}{|c|}{$\begin{array}{l}\text { DPF } \\
51-70 \\
\end{array}$} & \multicolumn{2}{|c|}{$\begin{array}{l}\text { DPF } \\
71-90\end{array}$} & \multicolumn{2}{|c|}{$\begin{array}{l}\text { DPF } \\
91-140\end{array}$} & \multicolumn{2}{|c|}{ Adult } \\
\hline & ISH & IHC & ISH & IHC & ISH & IHC & ISH & $\mathrm{IHC}$ & ISH & IHC & ISH & $\mathrm{IHC}$ & ISH & IHC & ISH & $\mathrm{IHC}$ & ISH & IHC & ISH & IHC \\
\hline \multicolumn{21}{|l|}{ Brain } \\
\hline Neurones & - & - & + & + & ++ & ++ & +++ & +++ & +++ & +++ & + & + & + & $+/-$ & + & $+/-$ & + & $+/-$ & + & $+/-$ \\
\hline Meninges & + & + & + & + & + & + & + & + & + & $+/-$ & + & $+/-$ & $+/-$ & $+/-$ & $+/-$ & $+/-$ & $+/-$ & $+/-$ & $+/-$ & $+/-$ \\
\hline \multicolumn{21}{|l|}{ Pituitary } \\
\hline $\begin{array}{l}\text { posterior } \\
\text { G-I tract }\end{array}$ & \multicolumn{19}{|c|}{ G-I tract } & $+/-$ \\
\hline Stomach & - & - & - & - & ++ & ++ & ++++ & ++++ & ++++ & ++++ & +++ & +++ & ++ & ++ & $+/-$ & $+/-$ & $+/-$ & $+/-$ & $+/-$ & $+/-$ \\
\hline Intestine & ++++ & ++++ & ++++ & ++++ & +++ & ++++ & ++++ & ++++ & ++++ & ++++ & ++ & ++ & + & + & $+/-$ & $+/-$ & $+/-$ & $+/-$ & $+/-$ & $+/-$ \\
\hline Liver & ++ & - & ++ & + & +++ & + & +++ & + & +++ & ++ & +++ & ++ & +++ & + & +++ & $+/-$ & +++ & - & +++ & - \\
\hline \multicolumn{21}{|l|}{ Pancreas } \\
\hline endocrine & - & - & + & + & + & + & + & + & ++ & ++ & ++ & ++ & ++ & ++ & ++ & ++ & ++ & ++ & ++ & ++ \\
\hline Gills & - & - & +++ & +++ & +++ & +++ & +++ & +++ & +++ & +++ & +++ & +++ & +++ & +++ & +++ & +++ & +++ & +++ & +++ & +++ \\
\hline Kidney & - & - & - & - & ++ & ++ & +++ & +++ & ++ & ++ & ++ & ++ & ++ & ++ & + & + & + & + & + & + \\
\hline Heart & - & - & - & - & - & - & + & + & +++ & + & ++ & + & + & + & + & + & - & - & - & - \\
\hline \multicolumn{21}{|l|}{ Cartilage } \\
\hline Chondrocytes & ++ & + & +++ & +++ & +++ & +++ & +++ & +++ & +++ & +++ & +++ & +++ & +++ & +++ & ++ & ++ & + & + & + & + \\
\hline Perichondrium & + & + & ++ & ++ & ++ & ++ & ++ & ++ & ++ & ++ & + & ++ & + & + & + & + & + & + & + & + \\
\hline Muscle & + & + & ++ & ++ & +++ & +++ & +++ & +++ & ++++ & ++++ & ++ & ++ & ++ & ++ & ++ & ++ & + & + & + & + \\
\hline Epidermis & + & + & + & + & + & + & ++ & ++ & +++ & +++ & + & + & + & + & $+/-$ & $+/-$ & $+/-$ & $+/-$ & $+/-$ & $+/-$ \\
\hline
\end{tabular}

- none, + /- very few, + some, ++ moderate, +++ majority, ++++ overall 
$\mathrm{pH} 7.4,2 \mathrm{mM} \mathrm{CaCl}_{2}$ for $10 \mathrm{~min}$ at $37^{\circ}$, treated with $1.5 \%$ triethanolamine and $0.25 \%$ acetic anhydride for $10 \mathrm{~min}$ at room temperature and incubated with $50 \mu \mathrm{l}$ prehybridization solution per section for $3-4 \mathrm{~h}$ at $54^{\circ} \mathrm{C}$. Hybridization was carried out overnight at $54^{\circ} \mathrm{C}$ with $30 \mu \mathrm{l}$ of hybridization buffer containing $10 \mathrm{ng}$ sense or antisense probe previously denaturated for $5 \mathrm{~min}$ at $85^{\circ} \mathrm{C}$. Slides were washed for $15 \mathrm{~min}$ at room temperature in $2 \times \mathrm{SSC}$ and for $30 \mathrm{~min}$ at the specific hybridization temperature at descending concentrations of SSC $(2 \times, 1 \times, 0,5 \times, 0,2 \times)$. The anti-DIG AP-coupled Ab was diluted $1: 4,000$ in $1 \%$ blocking reagent (Roche-Diagnostics) in buffer P1 and applied to the sections for $1 \mathrm{~h}$ at room temperature in the dark. After being washed twice in P1 for $15 \mathrm{~min}$, the sections were treated with buffer P3, $5 \mathrm{mM}$ levamisole and NBT/BCIP stock solution (Roche Diagnostics). Colour development was carried out overnight at room temperature and stopped by rinsing in tap water for $15 \mathrm{~min}$.

\section{Immunohistochemistry}

Sections were cut at $4 \mu \mathrm{m}$, mounted onto glass slides (Menzel-Gläser) and dried overnight at $42^{\circ} \mathrm{C}$. After being dewaxed and rehydrated, they were used for immunohistochemistry. To reduce unspecific binding, sections were treated with PBS $(\mathrm{pH} 7.4)$ containing $2 \%$ bovine serum albumin for $30 \mathrm{~min}$ at room temperature. Thereafter, the sections were incubated overnight with rabbit antiserum
116 raised against human IGF-I (Reinecke et al. 1997; Schmid et al. 1999) diluted at 1:400 and washed repetitively in PBS. The IGF-I antiserum was detected by incubation with biotinylated goat anti-rabbit IgG (Bioscience Products, Emmenbrücke, Switzerland; 1:100) for $30 \mathrm{~min}$ at room temperature. After repetitive rinses in PBS, the sections were incubated with streptavidin-fluoresceinisothiocyanate (Bioscience Products; 1:100) for $30 \mathrm{~min}$ at room temperature in the dark. The specificity of the reactions obtained was tested by using the following controls: (1) replacement of the primary antiserum by nonimmune rabbit serum, (2) pre-absorption of the primary antiserum with recombinant human (h) IGF-I, hIGF-II, porcine insulin (kind gift of Prof. J. Zapf, Zürich) or the peptide used for immunization ( $40 \mu \mathrm{g}$ or $400 \mu \mathrm{g}$ peptide $/ \mathrm{ml}$ diluted antiserum). Photomicroscopy was performed with a Zeiss Axioscope and Axiovision software 3.1. (Zeiss, Zürich, Switzerland).

\section{Results}

\section{General}

During early development, IGF-I mRNA and peptide were observed in all organs investigated. However, the onset of IGF-I expression and its duration differed considerably among the various tissues and organs (Table 1).
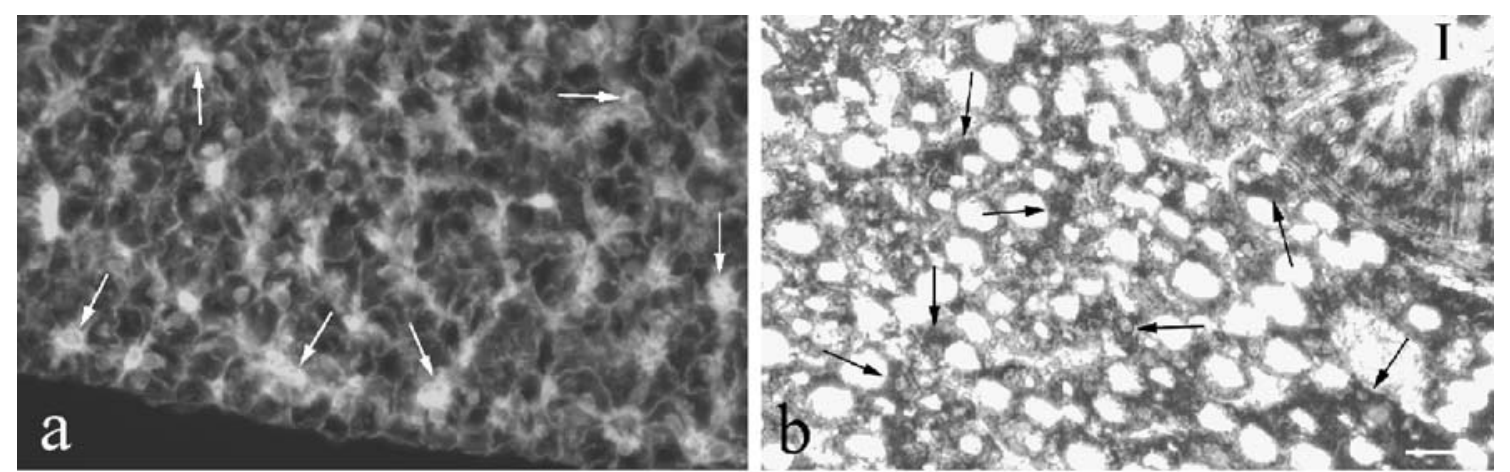

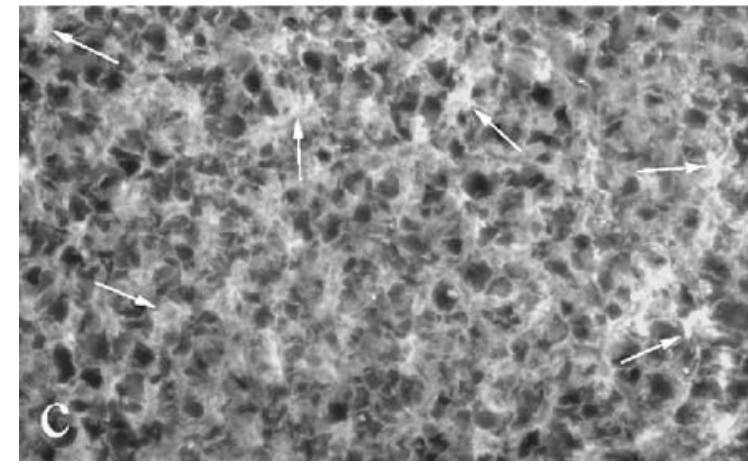

Fig. 1 IGF-I immunoreactivity $(\mathbf{a}, \mathbf{c})$ and $\mathrm{mRNA}(\mathbf{b}, \mathbf{d})$ in developing tilapia liver. a,b At 12 DPF, many hepatocytes exhibit IGF-I immunoreactivity (a, white arrows) and IGF-I mRNA (b, black arrows). Numerous mucosal epithelial cells of the intestine (I) contain

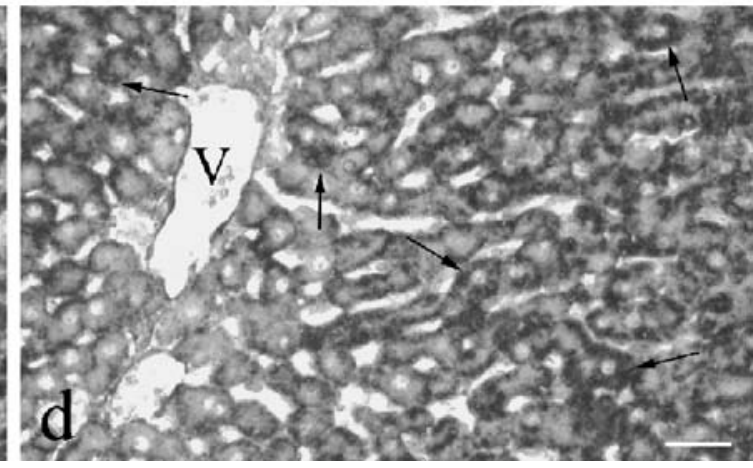

IGF-I mRNA (b). Bar $20 \mu \mathrm{m}$. c, d Tilapia liver at 36 DPF. IGF-I immunoreactivity of variable intensity (c, white arrows) and mRNA (d, black arrows) occur in numerous hepatocytes ( $V$ vein). Bars $30 \mu \mathrm{m}$ 
Liver

At $4 \mathrm{DPF}$, several hepatocytes started to exbibit IGF-I mRNA followed by IGF-I immunoreactivity around 6-7 DPF (Table 1). By 12 DPF, numerous hepatocytes showed IGF-I mRNA and some also contained IGF-I peptide (Fig. 1a,b). Around 36 DPF, a larger number of hepatocytes contained IGF-I mRNA (Fig. 1d) and about half of the hepatocytes also possessed IGF-I immunoreactivity at variable intensity (Fig. 1c). Whereas the expression of IGFI mRNA persisted in hepatocytes, the presence of IGF-I peptide decreased with age and could not be detected after 90 DPF.

\section{Gastro-intestinal tract}

IGF-I mRNA and peptide appeared in cells of the intestinal mucosal epithelium at 5 DPF (Fig. 2a,b). At 9 DPF, they were also detected in cells of the stomach epithelium. Virtually all epithelial cells of the gastro-intestinal tract contained IGF-I mRNA and peptide. IGF-I-immunore- active material was mainly located in the cell apex (Fig. 2a,c,d). The largest numbers of mucosal epithelial cells exhibiting IGF-I mRNA and peptide were found at 1329 DPF (Fig. 2c-e, Table 1). Around 17 DPF, additional IGF-I-containing cells were detected with the typical appearance of endocrine cells (Fig. 2c). These IGF-Iimmunoreactive cells occurred in all portions of the gastrointestinal tract but their distribution and frequency varied largely among different individuals. The cells persisted until the adult stage, whereas the presence of IGF-I immunoreactivity in the cell apex was limited to about 50 DPF (Table 1).

\section{Pancreas}

In the exocrine pancreas, the first cells with IGF-I mRNA were present as early as $4 \mathrm{DPF}$. Their number increased at around 6 DPF (Fig. 2f) and persisted at a high level until 18 DPF (Table 1). Thereafter, the number of IGF-I-containing acinar cells decreased until about 90 DPF and could not be detected in adults.
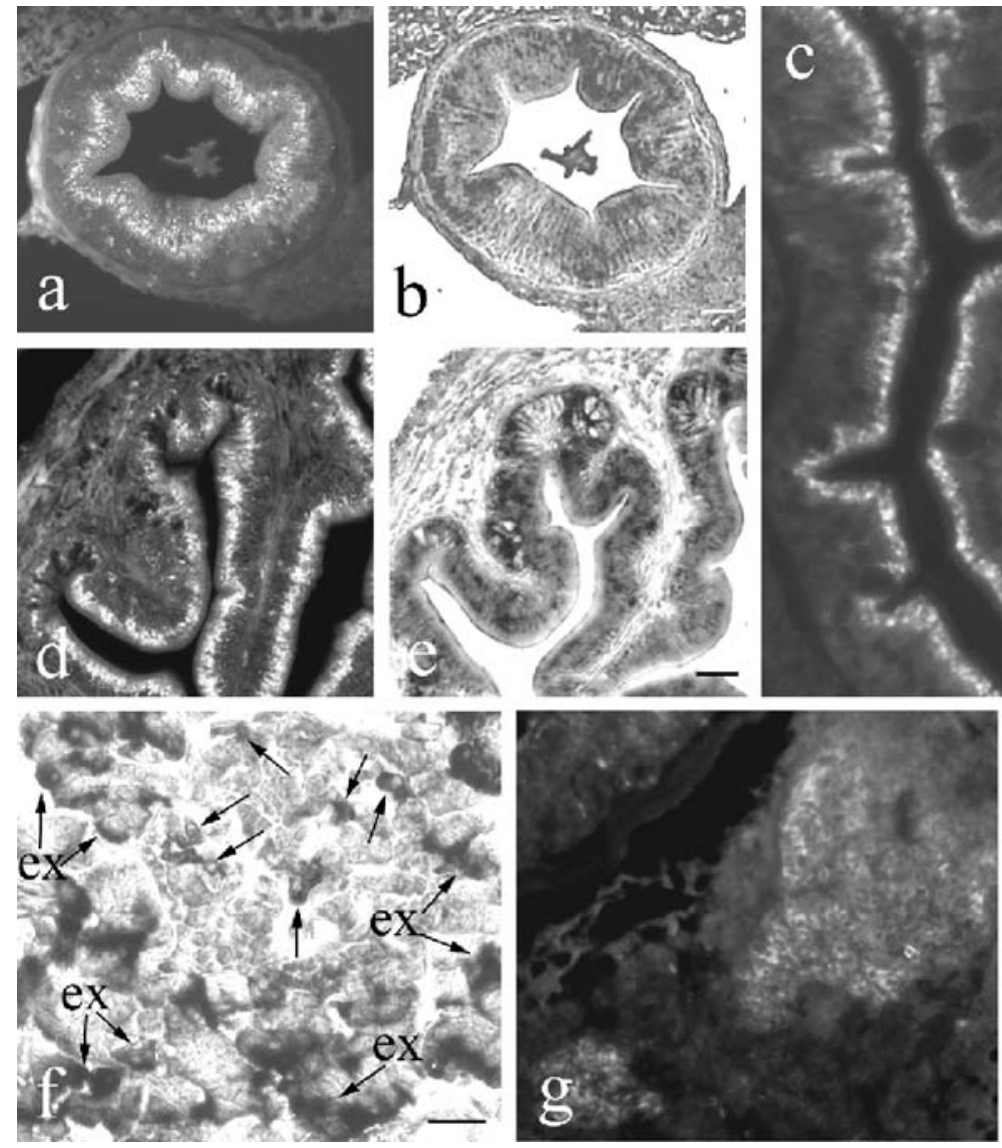

IGF-I mRNA (e). Bar $40 \mu \mathrm{m}$. f At 6 DPF, several endocrine cells in the islet contain IGF-I mRNA (arrows). Numerous acinar cells of the surrounding exocrine pancreas (ex, arrows) also exhibit IGF-I mRNA. Bar $25 \mu \mathrm{m}$. g At 76 DPF, no IGF-I immunoreactivity is observed in the exocrine pancreas but numerous cells in the islets are IGF-I-immunoreactive. As shown by double immunofluorescence, these cells constitute a subpopulation different from insulinimmunoreactive cells (h). Bar $25 \mu \mathrm{m}$
Fig. 2 IGF-I immunoreactivity and mRNA in developing tilapia epithelial cells in the developing intestine show IGF-I immunoreactivity in the apex (a) and also IGF-I mRNA (b) on consecutive sections. Bar $25 \mu \mathrm{m}$. c At $17 \mathrm{DPF}$, additional IGF-I-containing cells (arrows) are found with the typical appearance of endocrine cells. Bar $25 \mu \mathrm{m}$. d, e At $29 \mathrm{DPF}$, numerous cells in the mucosal epithelium of the stomach are IGF-I-immunoreactive (d) and contain

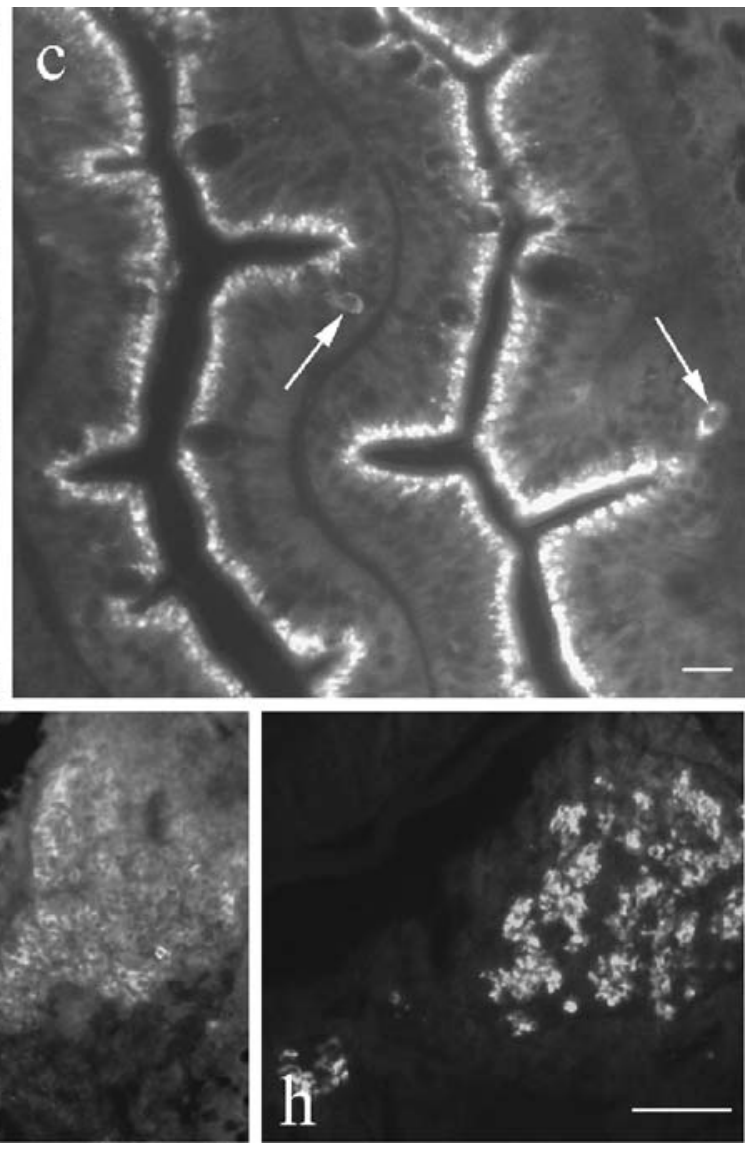


At 6 DPF, some islet cells appeared containing IGF-I mRNA (Fig. 2f) and peptide. Their number increased until 18 DPF. The IGF-I-containing islets cells did not contain insulin (Fig. 2g,h).

\section{Kidney}

At 8 DPF, IGF-I immunoreactivity (Fig. 3a) and mRNA appeared in the vast majority of renal vesicles and in the pronephric ducts. Faint IGF-I immunoreactivity (Fig. 3b) and mRNA were present in the renal tubules forming around $13 \mathrm{DPF}$. In the pronephric ducts, IGF-I immunoreactivity was located in the apical cell portion (Fig. 3a,b). Around 17 DPF, the epithelial cells of the pronephric urinary ducts (Fig. 3c) contained strong IGF-I immunoreactivity in the cell apex. Furthermore, numerous proximal tubules exhibited IGF-I mRNA (Fig. 3d) and immunoreactivity (Fig. 3e), whereas most of the distal tubules showed only faint reactions (Fig. 3e). This distribution pattern persisted until 25 DPF (Fig. 3f). Later, some proximal and distal tubules contained IGF-I immunoreactivity (Fig. 3g) and mRNA. In addition, strong IGF immunoreactivity was present in the apical cell portions of the collecting ducts (Fig. 3g). The same distribution pattern was also found in juvenile and adult tilapia (Table 1).

\section{Cartilage}

Even at 4-5 DPF, IGF-I mRNA and peptide were present in cartilage (Table 1). The expression of IGF-I was most pronounced in growing regions (Fig. 4a,b). Numerous chondrocytes expressing IGF-I were found in the cartilage
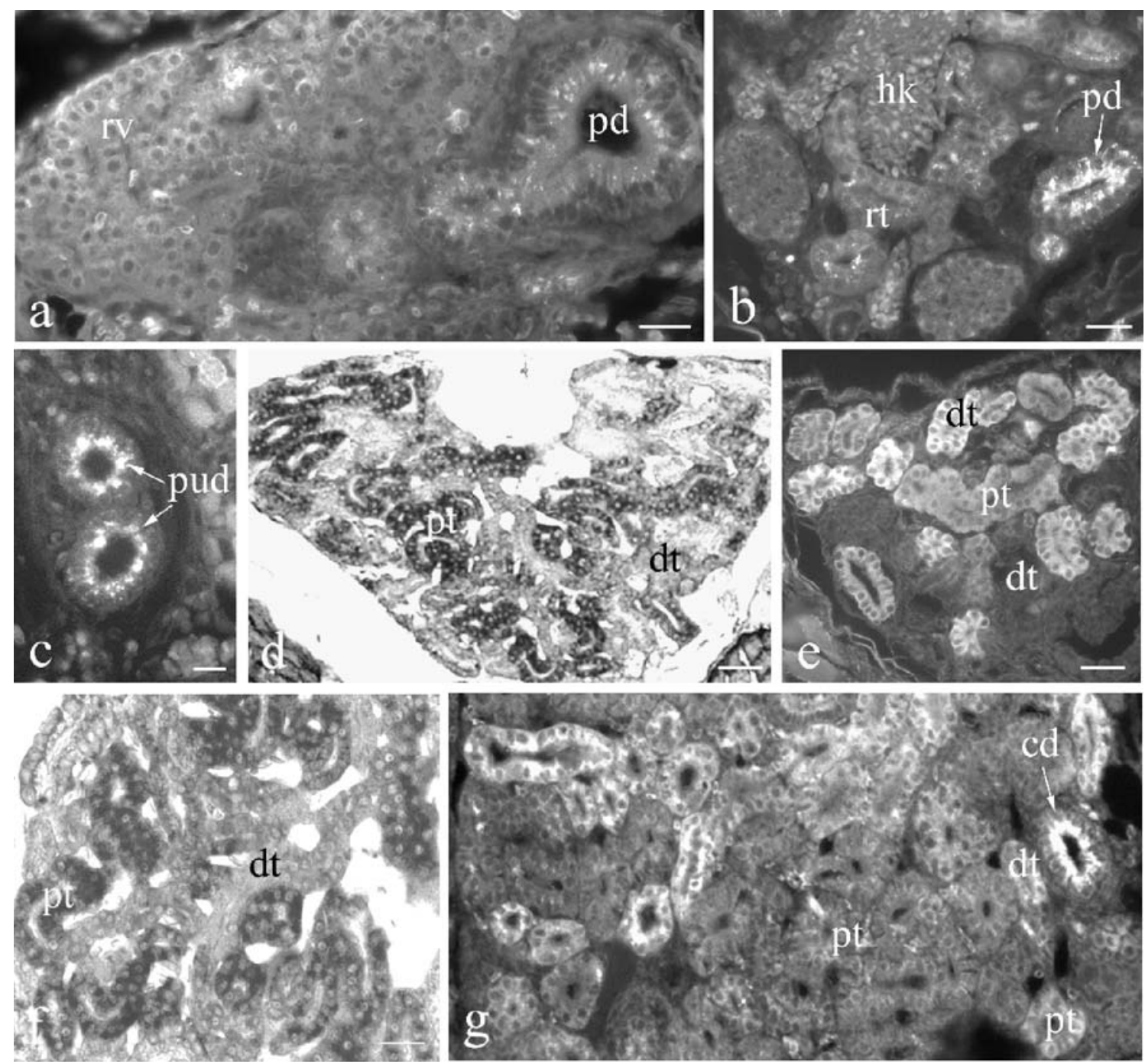

Fig. 3 IGF-I in developing kidney. a At 8 DPF, IGF-I immunoreactivity is present in most of the renal vesicles $(r v)$ and in the pronephric duct $(p d)$. Bar $25 \mu \mathrm{m}$. b At $13 \mathrm{DPF}$, several renal tubules $(r t)$ contain faint IGF-I immunoreactivity. In the pronephric duct $(p d)$, IGF-I immunoreactivity is located in the apical cell portion $(h k$ head kidney). Bar $30 \mu \mathrm{m}$. c-e Epithelial cells of the pronephric urinary ducts $(p u d)$ show strong IGF-I immunoreactivity in the apex at 17 DPF. Numerous proximal (pt) and distal $(d t)$ tubules exhibit IGF-I mRNA (d) and immunoreactivity (e). Bars $20 \mu \mathrm{m}$ (c), $30 \mu \mathrm{m}$ (d), $20 \mu \mathrm{m}$ (e). f At $25 \mathrm{DPF}$, most of the proximal tubules ( $p t)$ contain IGF-I mRNA but no expression is seen in the distal tubules (dt). Bar $20 \mu \mathrm{m}$. g At $29 \mathrm{DPF}$, some proximal $(p t)$ and distal $(d t)$ tubules and a collecting duct $(c d)$ show IGF-I immunoreactivity. Bar $15 \mu \mathrm{m}$ 
at various locations (Figs. 4c,d,g, 5a, 6a,d) throughout development. Their number slowly decreased with time and they were also found in adult life.

IGF-I was also detected by in situ hybridization and immunohistochemistry in the perichondrium starting at 4 DPF. The expression of IGF-I in the perichondrium was most pronounced between 6 and 50 DPF (Table 1) and persisted throughout life at a moderate level.

Muscle

IGF-I mRNA and peptide appeared in skeletal muscle fibers at 4 DPF (Table 1). Both were present in the cytoplasm (Fig. 4e,f). The highest expression of IGF-I in skeletal muscle was between 8 and 29 DPF (Table 1). Thereafter, it decreased (Fig. 4g) but persisted throughout development and adult life.

\section{Gills}

The production of IGF-I in gills had its onset at 6 DPF (Fig. 5a; Table 1). From the beginning, both IGF-I mRNA and peptide occurred in the majority of chloride cells. This distribution pattern was found throughout development (Fig. 5b,c) and adult life.
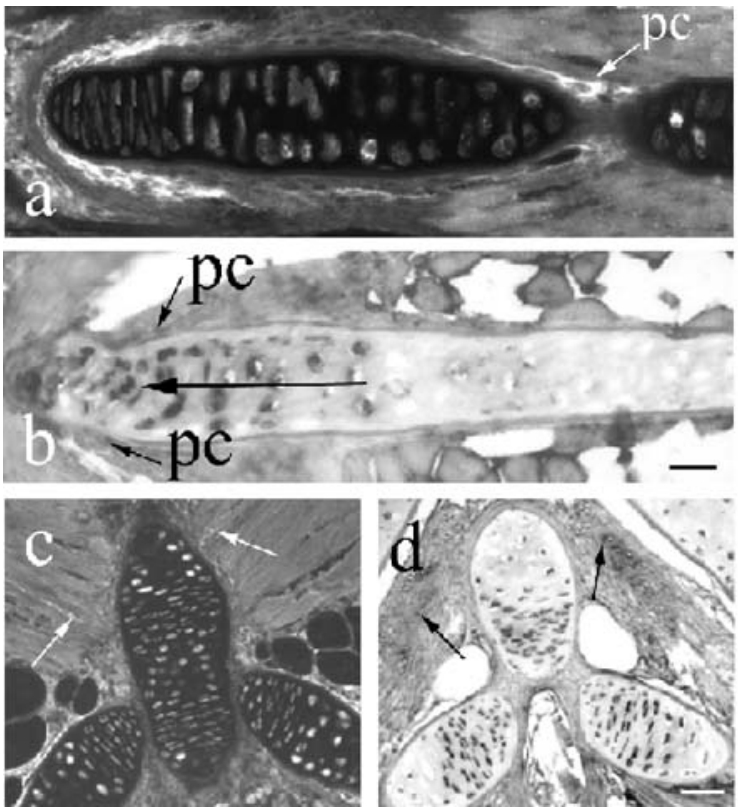

Fig. 4 IGF-I in developing cartilage (a-d) and skeletal muscle $(\mathbf{e}-\mathbf{g})$. a At $10 \mathrm{DPF}$, most chondrocytes and the perichondrium ( $p c)$ contain IGF-I immunoreactivity. b The expression of IGF-I mRNA is particularly pronounced in growing regions (large arrow) at 17 DPF. IGF-I mRNA further occurs in the perichondrium $(p c)$. Bar $15 \mu \mathrm{m}(\mathbf{a}, \mathbf{b})$. IGF-I immunoreactivity
Heart

At 13 DPF, IGF-I was first detected in the developing heart (Table 1). IGF-I was present both in atrial (Fig. 5d) and ventricular (Fig. 5e) myocardiocytes. The highest amount of IGF-I-containing myocardiocytes was present from 19 to 29 DPF. In general, the number of cells showing IGF-I mRNA was higher than that of cells exhibiting IGF-I immunoreactivity (Table 1). During late development and in adults, no IGF-I could be detected in the heart.

\section{Brain}

In brain, strong IGF-I mRNA signals were revealed in numerous neurones of the brain of larvae (Fig. 6a) starting around 6 DPF (Table 1). Similarly, IGF-I immunoreactivity was present in the vast majority of neurones (Fig. 6c). In addition, IGF-I was expressed in spinal (Fig. 6d) and in developing autonomic ganglia. This overall neuronal presence of IGF-I persisted until about 29 DPF and slowly decreased thereafter. In older larvae and adult individuals, IGF-I mRNA and peptide, although still found at all levels of brain and spinal cord, were present in some neurones only. In the older fish, the number of neurones containing IGF-I mRNA exceeded that of the IGF-I-immunoreactive neurones. Whereas in most areas of the brain, the distribution patterns of IGF-I mRNA and peptide varied largely among the individuals investigated, the Purkinje cells in the cerebellum always showed IGF-I peptide (Fig. 6e) and mRNA (Fig. 6f). Starting at 4 DPF, IGF-I
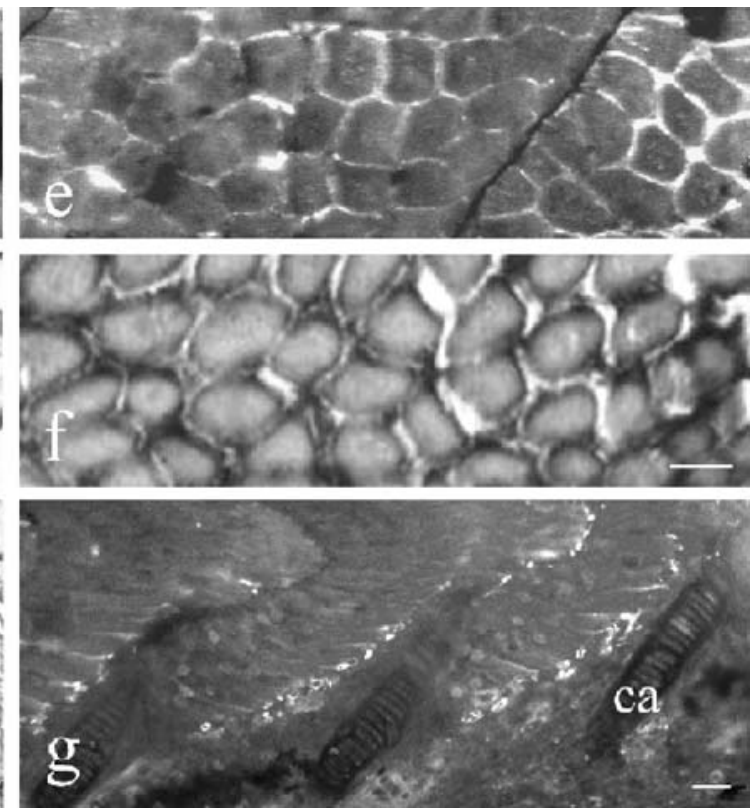

(c) and mRNA (d) are present in the majority of chondrocytes of spine and rib cartilage and in skeletal muscle (arrows) at 20 DPF. Bar $30 \mu \mathrm{m}$. IGF-I immunoreactivity (e) and mRNA (f) are found in the cytoplasm of all skeletal muscle fibers at 17 DPF. Bar $10 \mu \mathrm{m}$. g At $50 \mathrm{DPF}$, numerous muscle fibers still show IGF-I immunoreactivity ( $c a$ cartilage). Bar $50 \mu \mathrm{m}$ 


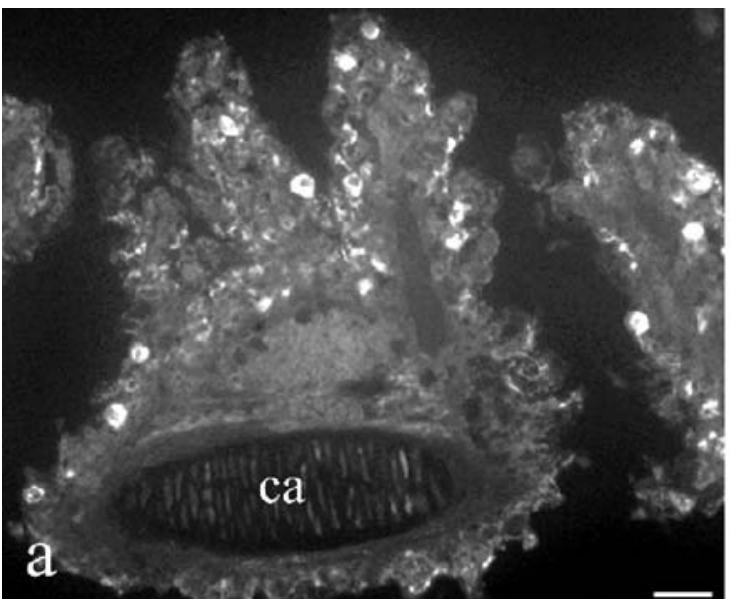

Fig. 5 IGF-I immunoreactivity and mRNA in gills $(\mathbf{a}-\mathbf{c})$ and heart (d, e). a At 6 DPF, IGF-I immunoreactivity is present in numerous chloride cells and also occurs in gill cartilage $(c a)$. Bar $45 \mu \mathrm{m}$. b, c The production of IGF-I is found in most

immunoreactivity and mRNA were observed in the meninges (Fig. 6a). The expression of IGF-I persisted at
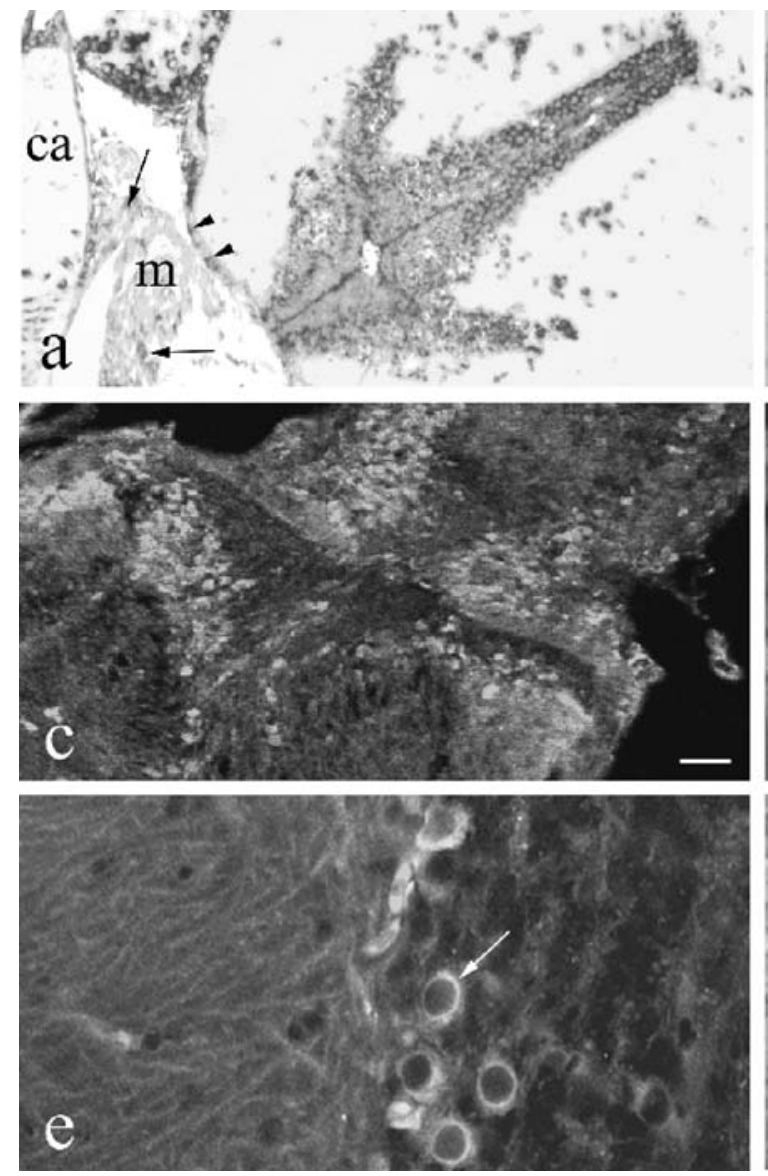

Fig. 6 IGF-I in the central and peripheral nervous systems. a, b In situ hybridization of serial sections of tilapia brain with an IGF-I antisense probe (a) and an IGF-I sense probe (b) at 20 DPF. Abundant neurons exhibit IGF-I mRNA (a) whereas no IGF-I mRNA is located in the negative control (b). IGF-I mRNA also occurs in the meninges (arrowheads), in chondrocytes of the cartilage $(\mathrm{ca})$ and in skeletal muscle cells (arrows, $\mathrm{m}$ ). Bar 40

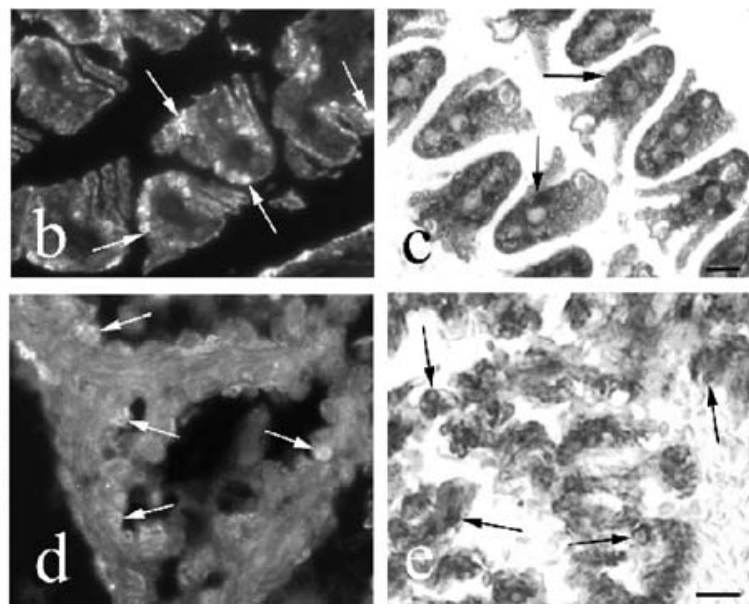

chloride cells (arrows) in later development as shown for 70 DPF. Bar $20 \mu \mathrm{m}$. d, e The presence (arrows) of IGF immunoreactivity (d) and mRNA (e) in cardiomyocytes of the developing heart at 29 DPF. Bar $20 \mu \mathrm{m}$

the initial level until 50 DPF but stayed at a low level throughout life (Table 1).
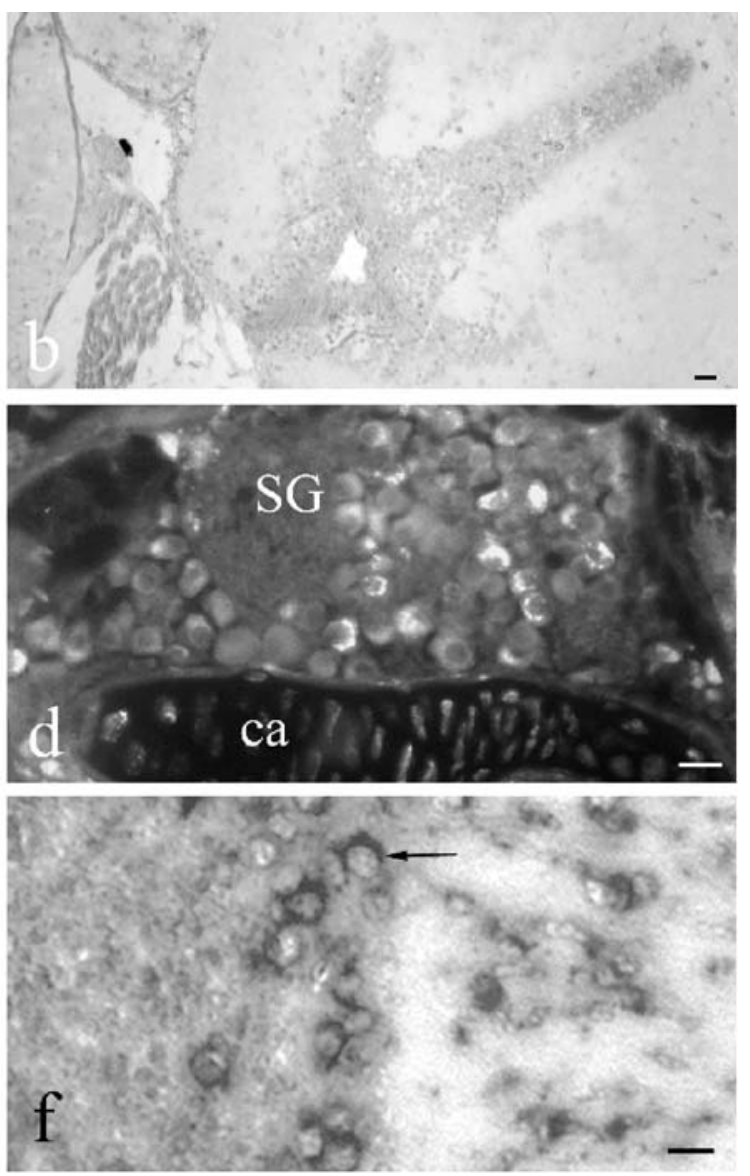

$\mu \mathrm{m}$. c IGF-I immunoreactivity is present in numerous central neurones at 20 DPF. Bar $100 \mu \mathrm{m}$. d Several neurones in the spinal ganglion $(S G)$ exhibit IGF-I immunoreactivity ( $c a$ cartilage). Bar $20 \mu \mathrm{m}$. e, f At $70 \mathrm{DPF}$, Purkinje cells (arrows) in the cerebellum contain IGF-I peptide (e) and IGF-I mRNA (f). Bar $25 \mu \mathrm{m}$ 
Pituitary

IGF-I occurred in both portions of the tilapia pituitary but appeared later than in brain. The first neurosecretory axons containing IGF-I immunoreactivity (Fig. 7a,c) appeared in the posterior (neuro-) pituitary around 17 DPF (Table 1). Their density decreased with age but they were still detected in adults. No IGF-I mRNA was detected in the posterior pituitary. IGF-I-immunoreactive neurons occurred in hypothalamus (Fig. 7c). Endocrine cells of the anterior (adeno-) pituitary first exhibited IGF-I mRNA at 28 DPF (Fig. 7b) followed by IGF-I immunoreactivity at 40 DPF (Fig. 7c). IGF-I immunoreactivity (Fig. 7c) and mRNA (Fig. 7d) in endocrine cells were present throughout development and in adults.

Skin

At 5 DPF, IGF-I immunoreactivity appeared in cells of the epidermis (Fig. 8a). First, the number of epidermal cells exhibiting IGF peptide (Fig. 8b) and mRNA (Fig. 8c) increased with age to reach the highest level around 19-29
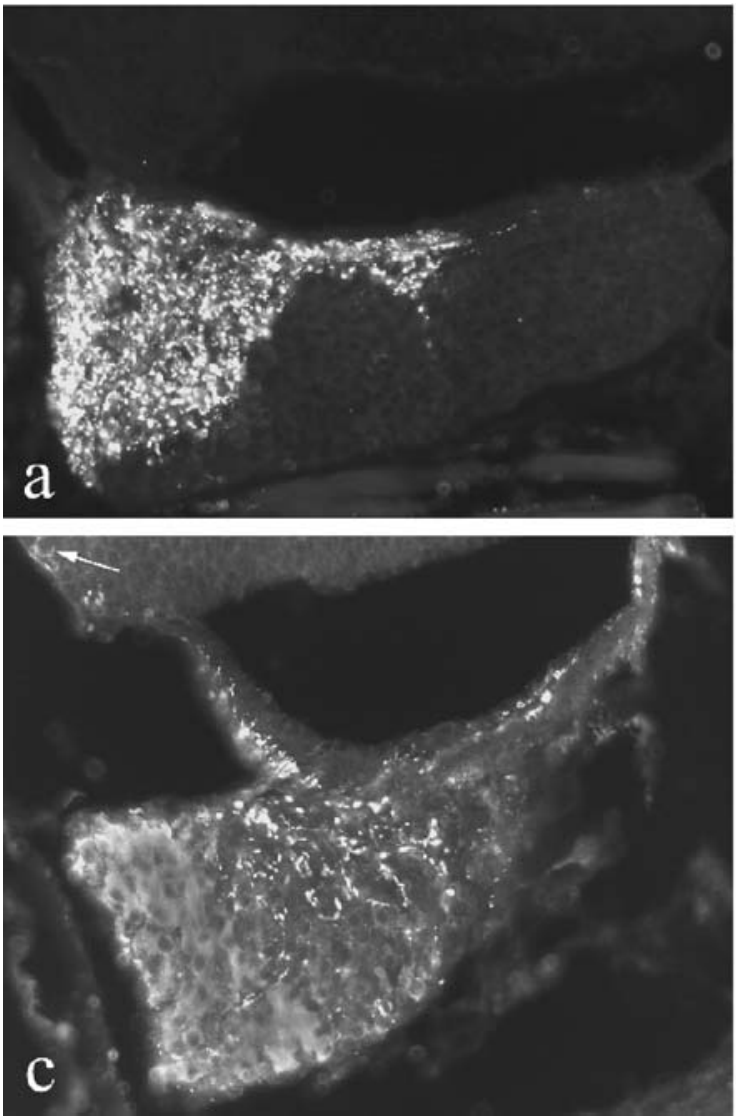

Fig. 7 IGF-I immunoreactivity and mRNA in the pituitary as revealed in two pairs of consecutive sections (a, b and $\mathbf{c}, \mathbf{d})$ processed for immunofluorescence $(\mathbf{a}, \mathbf{c})$ and in situ hybridization (b, d). a, b At 28 DPF, numerous axons in the neuropituitary contain IGF-I immunoreactivity (a) but no IGF-I mRNA is present (b). In the adenopituitary, most of the endocrine cells exhibit IGF-I mRNA (b), whereas they do not show IGF-I immunoreactivity (a). Most
DPF (Table 1). In older larvae (Fig. 8d,e) and adults, some superficial epidermal cells (arrows) and occasionally also cells in the basal epidermis (arrowhead) were IGF-Iimmunoreactive or contained IGF-I mRNA (Fig. 8e).

\section{Discussion}

This study has revealed the appearance and distribution of IGF-I mRNA and peptide during the early development of the tilapia, $O$. niloticus. Both IGF-I mRNA and peptide have been observed in parenchymal cells of all organs investigated but the onset, intensity and duration of IGF-I expression differs considerably among the various tissues and organs.

Both IGF-I mRNA and peptide appear in liver at 4 DPF. This early onset of IGF-I production in tilapia liver is in agreement with results obtained in shi drum in which IGF-I immunoreactivity has been detected in hepatocytes during the first week post hatching (Radaelli et al. 2003). Because liver is the main source of endocrine IGF-I, these results suggest a particular physiological impact of circulating IGF-I in early development. Although high expression of

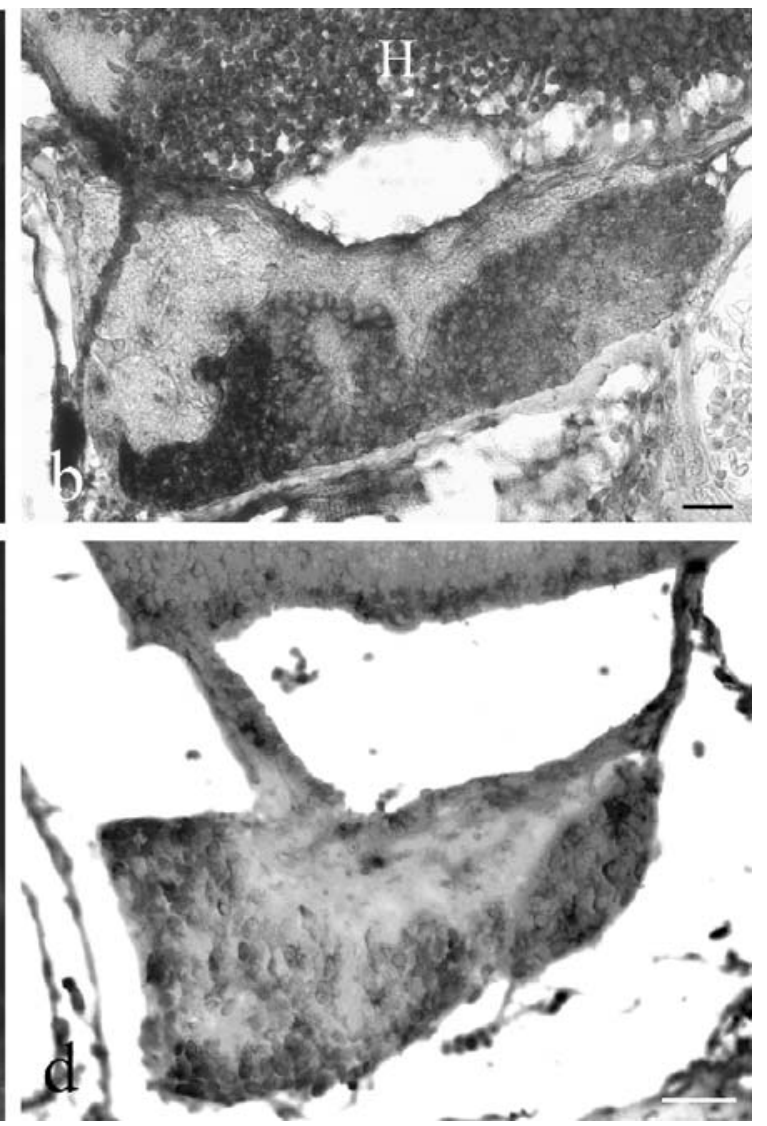

neurons in the hypothalamus $(H)$ exhibit IGF-I mRNA (b). Bar $40 \mu \mathrm{m}$. c, d At 40 DPF, both IGF-I immunoreactivity (c) and mRNA (d) are detectable in endocrine cells of the anterior pituitary. IGF-Iimmunoreactive axons are present in the posterior part. An IGF-Iimmunoreactive neuron (c, arrow) is shown in the hypothalamus. Bar $70 \mu \mathrm{m}$ 

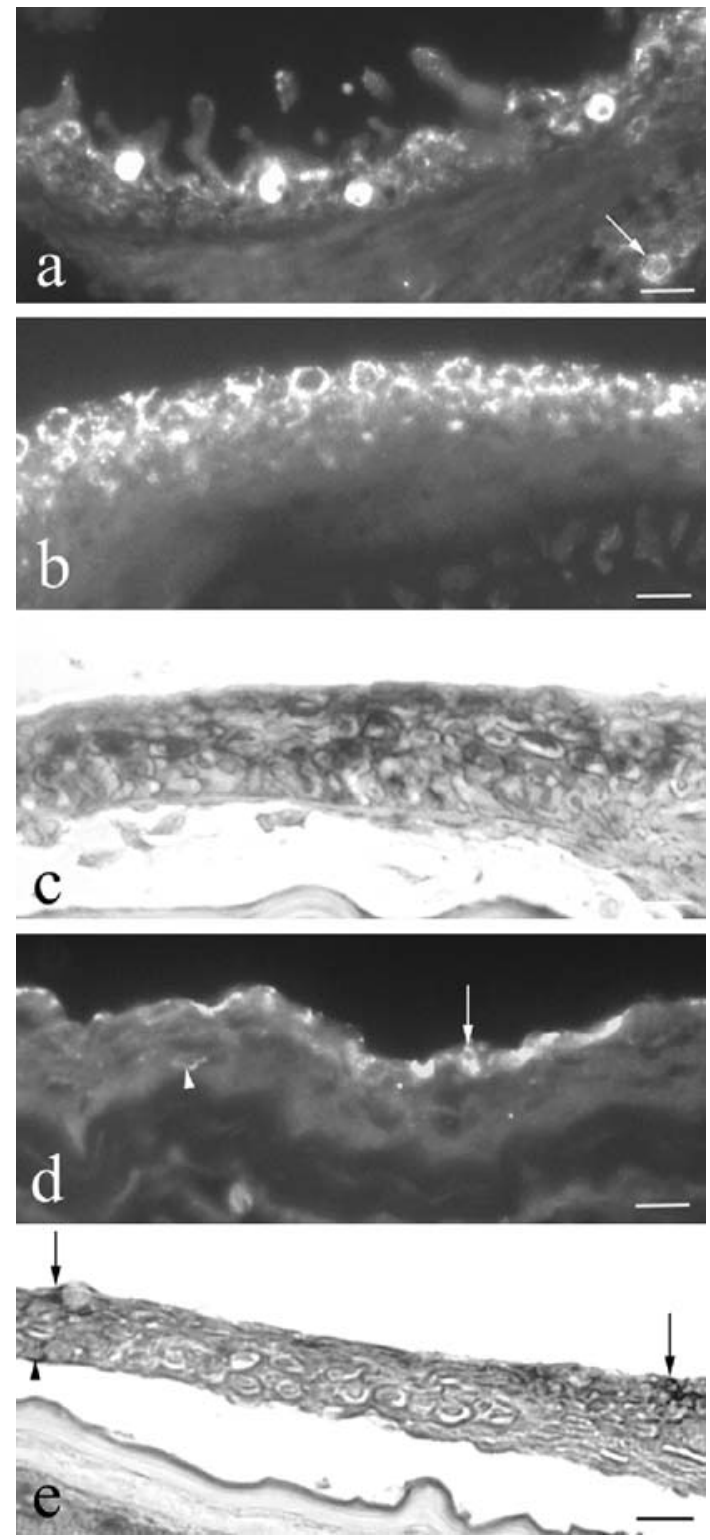

Fig. 8 IGF-I immunoreactivity and mRNA in the skin. a At 5 DPF, several cells in the epidermis contain IGF-I immunoreactivity. In the dermis, a possible dendritic cell also shows IGF-I immunoreactivity (arrow). Bar $40 \mu \mathrm{m}$. b, c At 25 DPF, numerous cells in all epidermal layers exhibit IGF-I peptide (b) and mRNA (c). Bar $30 \mu \mathrm{m}$. d, e Frequent superficial epidermal cells (arrows) and infrequent basal epidermal cells (arrowheads) exhibit IGF-I immunoreactivity (d) and mRNA (e) at 36 DPF. Bars $50 \mu \mathrm{m}(\mathbf{d})$, $40 \mu \mathrm{m}(\mathbf{e})$

IGF-I mRNA has been detected throughout life in tilapia liver, IGF-I immunoreactivity decreases with age and is present only until about 70 DPF. In contrast to an earlier study on sea bream (Funkenstein et al. 1997), an intense response by in situ hybridization for IGF-I has been obtained in adult tilapia liver. In spite of the clear expression of IGF-I mRNA in adult tilapia liver (Schmid et al. 1999), no IGF-I-immunoreactive hepatocytes have been identified in adult barramundi (Richardson et al. 1995) and tilapia (Reinecke et al. 1997; Schmid et al. 1999). Similarly, in rat liver, IGF-I immunoreactivity has been localized only after pretreatment with colchicine (Hansson et al. 1988). Therefore, IGF-I might be released from fish liver into the circulation immediately after synthesis, as has previously been presumed in mammals (Hansson et al. 1988).

High-affinity hepatic-binding sites for growth hormone (GH) have been identified in the liver of several fish species, including tilapia ( $\mathrm{Ng}$ et al. 1992). In accordance, there is strong evidence that GH stimulates IGF-I expression in fish liver and its secretion into the circulation (see Reinecke et al. 2005). Injection or oral administration of GH significantly enhances the IGF-I mRNA level in the liver of numerous species (e.g. Duan et al. 1993; Duguay et al. 1994, 1996; Moriyama 1995; Shamblott et al. 1995; Shepherd et al. 1997; Vong et al. 2003; Biga et al. 2004). The GH-induced increase in liver IGF-I mRNA expression is accompanied by an increase in the level of circulating IGF-I (Funkenstein et al. 1989; Niu et al. 1993; Moriyama et al. 2000). In addition to these in vivo studies, some in vitro investigations have also demonstrated the stimulating effect of GH on liver IGF-I mRNA expression, i.e. on primary cultured hepatocytes of salmonids (Duan et al. 1993; Shamblott et al. 1995; Pierce et al. 2005) and tilapia (Schmid et al. 2000). In rainbow trout, GH mRNA has been detected in early stage embryos (Yang et al. 1999). Thus, the production and release of liver IGF-I during tilapia early development may be under the control of GH.

The early onset of the production of IGF-I in tilapia gastro-intestinal tract, i.e. at 5 DPF in intestine and at 9 DPF in stomach, supports the results of earlier studies. In the intestinal epithelium of turbot (Berwert et al. 1995) and shi drum (Radaelli et al. 2003), the first IGF-I-immunoreactive cells can be found as early as the first week post hatching. Furthermore, IGF-1R appears in the second week post hatching in shi drum gut (Radaelli et al. 2003). The number of IGF-I-producing cells in the developing bony fish gastro-intestinal tract by far exceeds that in the adult because, during ontogeny, almost all epithelial cells throughout the gastro-intestinal tract exhibit IGF-I mRNA and peptide. The IGF-I-immunoreactive material is mainly located in the cell apex as has also been reported in shi drum (Radaelli et al. 2003), possibly suggesting release into the lumen. Around 17 DPF, additional infrequent IGF-I-containing cells appear in the mucosal epithelium; these cells have the typical appearance of endocrine cells as characterized for adult fish (Reinecke et al. 1997; Koppang et al. 1998). The distribution of these IGF-I-immunoreactive cells in the various portions of the adult gastro-intestinal tract and their frequency vary largely among different individuals, as previously reported in turbot (Berwert et al. 1995) and Atlantic salmon (Koppang et al. 1998).

Although the early and overall appearance of IGF-I and its receptor strongly suggests a particular physiological impact of IGF-I in the developing gastro-intestinal tract, we can only hypothesize on the physiological meaning of intestinal IGF-I in fish. IGF-I secreted from the IGF-Iimmunoreactive epithelial cells may exert mitogenic functions by acting on neighbouring epithelial cells. This 
hypothesis is supported by results obtained in mammals. In pig, the amounts of intestinal IGF-I immunoreactivity and of the IGF-1R can be correlated with villous growth and maturation (Schober et al. 1990) and, in adult rat, IGF-I potently stimulates crypt cell proliferation and villus cell density (Steeb et al. 1994). The potential proliferative action of intestinal IGF-I during development and adult life may be regulated by $\mathrm{GH}$, which markedly increases the amount of intestinal IGF-I mRNA in juvenile common carp (Vong et al. 2003) and adult rainbow trout (Biga et al. 2004).

In juvenile and adult bony fish, IGF-I released from the infrequent IGF-I-immunoreactive mucosal epithelial cells may exert paracrine effects in response to altering local demands, such as repair. In agreement with this hypothesis, the therapeutical potential of IGF-I has been discerned for numerous acute human bowel disorders resulting in accelerated intestinal repair and epithelial regrowth (Howarth 2003). Because, in addition to gill and kidney, the intestinal tract exerts important osmoregulatory functions in fish, intestinal IGF-I may also be involved in osmoregulation (Koppang et al. 1998; Reinecke and Collet 1998). This hypothesis is supported by experiments in brown trout suggesting that IGF-I plays a role in the regulation of intestinal $\mathrm{Na}^{+}, \mathrm{K}^{+}$-ATPase activity (Seidelin and Madsen 1999).

IGF-I immunoreactivity has been localized in cells of the exocrine parenchyma of shi drum and seabream larvae (Funkenstein et al. 1997; Perrot et al. 1999; Radaelli et al. 2003); this is supported by the results of the present study. As IGF-I production in pancreas is stimulated by GH in rat (Jevdjovic et al. 2004), IGF-I in fish pancreas may also be under the control of $\mathrm{GH}$, although no results have been presented to date on the potential regulation of IGF-I in the exocrine pancreas.

To date, indications for the presence of IGF-I in the endocrine pancreas have only been obtained by immunohistochemical studies. These have shown that IGF-I immunoreactivity occurs in islet cells of several bony fish species (Reinecke et al. 1993, 1997; Berwert et al. 1995; Richardson et al. 1995). The present study provides the additional information that IGF-I mRNA is also present in islet cells. This is supported by molecular biological studies that have shown IGF-I mRNA expression in principal islets of the salmon $O$. gorbusha (Plisetskaya et al. 1993) and of Cottus scorpius (LoffingCueni et al. 1998). Islet IGF-I appears at 6 DPF in tilapia (this study) and day 10 post hatching in turbot (Berwert et al. 1995) suggesting a significant physiological role for islet-derived IGF-I during larval development. In both species, from the onset of its expression, IGF-I occurs in non-insulin cells. This observation is in agreement with studies on adult teleosts, such as eel, tilapia, goldfish, turbot and common carp (Reinecke et al. 1993, 1997; Berwert et al. 1995).

On the one hand, islet-derived IGF-I may be involved in the paracrine regulation of insulin secretion from the $\beta$ cells, although the evidence in mammals is conflicting (Leahy and Vandekerkhove 1990; Van Schravendijk et al. 1990; Jevdjovic et al. 2004). On the other hand, some studies suggest that islet-derived IGF-I may act as an endocrine hormone. Hypophysectomy does not influence the amount of sulphation activity in eel pancreas (Duan and Hirano 1992) suggesting that islet IGF-I is not regulated by $\mathrm{GH}$. In goby, islectomy leads to a decrease in ${ }^{35} \mathrm{SO}_{4}$ incorporation in cartilage (Bern et al. 1991) but hepatic GH binding is unchanged (Kelley et al. 1993). The observed effects may have been augmented by insulin (Plisetskaya 1998). However, in addition to the GHdependent liver IGF-I system, islet-derived IGF-I may constitute a further endocrine GH-independent IGF-I system involved in the regulation of fish growth.

No information is available on IGF-I in developing fish kidney. In adult bony fish, however, epithelial cells mainly of the proximal tubules have been reported as sites of IGF-I production in tilapia (Reinecke et al. 1997), as has similarly been described in adult mammals (see Reinecke and Collet 1998). In tilapia, IGF-I occurs in renal vesicles even at early stages of development, i.e. at 5 DPF. Later, it is present in proximal and distal tubles and in collecting and urinary ducts. Whereas IGF-I in the tubular sytem is detected throughout the cytoplasm, it occurs only in the apical cell part in the ducts possibly suggesting the release of IGF-I into the lumen. Apart from the gills, the kidney is a major osmoregulatory organ in fish but the evidence for the potential participation of renal IGF-I in osmoregulation is conflicting. In rainbow trout, transfer to seawater has been reported to increase the IGF-I mRNA level in kidney (Sakamoto and Hirano 1993). In contrast, the same treatment does not affect the $\mathrm{Na}^{+}, \mathrm{K}^{+}$-ATPase gene level and activity in brown trout (Madsen et al. 1995) or the renal IGF-I mRNA level in the four-spine sculpin, Cottus kazika (Inoue et al. 2003). Thus, at present, we can only speculate about the physiological role of IGF-I in bony fish kidney. In addition to its possible role in osmoregulation, renal IGF-I may be involved in several other parameters of kidney function, such as the stimulation of kidney growth and differentiation, renal blood flow, glomerular filtration rate and sodium absorption, as is likely in mammals (Hirschberg 1996).

In $O$. niloticus, IGF-I also appears early in tissues that are highly involved in growth, such as cartilage and skeletal muscle. At 4 DPF, IGF-I mRNA and peptide are present in the chondrocytes of cartilage at various locations. Similarly, in shi drum, IGF-I immunoreactivity has been observed in cartilage at day 11 post hatching (Radaelli et al. 2003). The expression of IGF-I in tilapia is most pronounced in growing regions. The number of IGFI-containing chondrocytes is higher during development than in adult life, thus underlining the physiological impact of local IGF-I during cartilage growth. Although the GH/liver IGF-I axis is involved in the regulation of fish growth as an endocrine system (Duan 1998; Reinecke et al. 2005), an influence of GH on growth via local auto/ paracrine IGF-I, as indicated by the present results, is also likely. An early study on eel has determined that the stimulatory effect of $\mathrm{GH}$ on sulphate incorporation into cartilage is mediated by an IGF-like plasma factor (Duan 
and Inui 1990). In agreement, the injection of GH into coho salmon cartilage stimulates sulphate and thymidine incorporation (McCormick et al. 1992; Tsai et al. 1994). Thus, GH may have increased both uptakes via the stimulation of local IGF-I, because IGF-I peptide and mRNA have been shown in chondrocytes of developing (Perrot et al. 1999; Radaelli et al. 2003; this study) and adult (Funkenstein et al. 1997; Reinecke et al. 1997) bony fish. The GH-dependent growth promoting effects of IGFI on cartilage may therefore be exerted not only via the endocrine route, but also in an autocrine/paracrine manner by IGF-I released from local chondrocytes, as has been shown in rat (Reinecke et al. 2000).

In contrast to the skeletal muscle of young shi drum larvae (Radaelli et al. 2003) in which no IGF-I immunoreactivity has been detected, the onset of IGF-I production in tilapia skeletal muscle occurs at 4 DPF, with IGF-I showing a maximum around 10-29 DPF, decreasing afterwards but persisting throughout life. In agreement with an auto/paracrine function of muscle IGF-I, IGF-I receptor number and binding in trout skeletal muscle are highest at 5 weeks and both parameters decrease with age (Mendez et al. 2001). Furthermore, a parallel age-related decline has been found for tyrosine kinase activity for IGF1R (Mendez et al. 2001). In rainbow trout muscle in vitro, IGF-I has been shown to be highly effective in stimulating glucose and alanine uptake into myosatellite cells, whereby the degree of stimulation changes when cells differentiate to myotubes (Castillo et al. 2004). These and the present results showing that IGF-I in skeletal muscle appears as early as 4 DPF and decreases with age indicate a key role for IGF-I in muscle development. IGF-I may be associated in later life with metabolism and repair mechanisms. In adult rainbow trout, the expression of IGF-I in skeletal muscle is stimulated by GH (Biga et al. 2005). Thus, GH may also regulate IGF-I production in larval musle.

Endocrine (liver-derived) IGF-I seems to have a physiological impact in smoltification. In mummichog (Fundulus heteroclitus; Mancera and McCormick 1998) and trout (Seidelin et al. 1999), IGF-I improves adaptation to seawater in a dose-dependent manner. The osmoregulatory effects of IGF-I seem to be exerted directly because, in preparations of Coho salmon gills in vitro, IGF-I stimulates $\mathrm{Na}^{+}, \mathrm{K}^{+}$-ATPase (Madsen and Bern 1993). Hypophysectomy in tilapia lowers the levels of gill $\mathrm{Na}^{+}$, $\mathrm{K}^{+}$-ATPase when compared with that of sham-operated controls (Shepherd et al. 1997) indicating an involvement of the GH/liver IGF-I axis. In agreement, in a study on Cottus kazika, the level of liver IGF-I mRNA has been shown to be significantly higher in individuals reared in seawater than in those reared in freshwater (Inoue et al. 2003). In sharp contrast, a study on Coho salmon has demonstrated that IGF-I mRNA is not significantly altered during seawater adaptation in liver but markedly increases in gills (Sakamoto and Hirano 1993). The chloride cells of filament epithelium have been shown not only to express $\mathrm{Na}^{+}, \mathrm{K}^{+}$-ATPase in trout (McCormick 1996), but also IGFI in tilapia (this study), in shi drum larvae (Radaelli et al. 2003) and in adult tilapia (Reinecke et al. 1997). GH receptors have been detected in tilapia gills (Fryer 1979) and GH treatment increases IGF-I mRNA in gills of salmonids and carp (Vong et al. 2003; Biga et al. 2004). Thus, in addition to circulating IGF-I, GH-regulated local autocrine/paracrine IGF-I in the chloride cells seems to participate in the regulation of plasma osmolality and gill $\mathrm{Na}^{+}, \mathrm{K}^{+}$-ATPase activity. Because the expression of IGF-I in tilapia gill chloride cells has been detected even around 6-7 DPF, IGF-I may exert additional functions, such as influencing the growth and maintenance of the filament epithelium.

In shi drum heart, IGF-I immunoreactivity has been detected in 15-day larvae (Radaelli et al 2003). Likewise, IGF-I mRNA and peptide appear at 13 DPF in tilapia. The expression of IGF-I in cardiomyocytes is clearly detectable until 70 DPF but is absent from later stages and adults indicating a particular physiological impact of IGF-I during heart development and growth. In correlation, a significant increase in IGF-1R mRNA levels (Gutiérrez et al. 1995) has been observed in the rapidly growing juvenile trout heart (Greene and Chen 1999). In fish heart, local IGF-I may be even more important than circulating IGF-I. In rainbow trout heart IGF-1R mRNA levels decrease after application of GH (Biga et al. 2004) and the number of IGF-I receptors is inversely related to the concentration of circulating IGF-I (Baños et al. 1997; Moon et al. 1996).

Screening studies have identified the potential sites of IGF-I synthesis in the brains of barramundi, tilapia and sea bream. IGF-I-immunoreactive neurones are present in adult barramundi brainstem (Richardson et al. 1995) and at all levels of adult tilapia brain (Reinecke et al. 1997). Correspondingly, IGF-I mRNA signals have been described throughout the brain of developing sea bream (Funkenstein et al. 1997). The functional impact of IGF-I in brain is indicated by the presence of IGF-1R in adult carp and trout brain (Leibush et al. 1996) and by the appearance of IGF-1R immunoreactivity in the developing brain of shi drum as early as hatching (Radaelli et al. 2003). In contrast to IGF-II (Caelers et al. 2003), the exact distribution of IGF-I gene expression in fish brain is unknown. The IGF-Iimmunoreactive neurones in barramundi and tilapia are sparsely scattered and their distribution exhibits pronounced inter-individual differences. In juvenile (this study) and adult tilapia (Reinecke et al. 1997) and adult daddy sculpin (Loffing-Cueni et al. 1998) brain, only IGFI-producing Purkinje cells in cerebellum are constantly present. In agreement with the potential autocrine/paracrine action of neuronal IGF-I in adult brown trout, Salmo trutta, IGF-I binding in the brain is highest in the cerebellum (Smith et al. 2005). The pronounced inter-individual variations of IGF-I-producing neurones in adult fish brain make a neurotransmitter or -modulator function of IGF-I unlikely. Rather, neuronal IGF-I may support the survival of neurones and glia cells, as is also likely for mammals (Cheng et al. 2001). During development, IGF-I may stimulate neurogenesis, dendritic growth and synaptogenesis in an autocrine/paracrine manner, as has been shown in mammals (e.g. Zhou et al. 1999; Niblock et al. 2000; Kakizawa et al. 2003). This hypothesis is supported by the 
observation that, in early developing tilapia larvae, most neurones express IGF-I mRNA and that the number of neurones containing IGF-I mRNA decreases with age. Whether the assumed actions of IGF-I are exerted under the control of GH is unclear at present, since GH significantly increases brain IGF-I mRNA in rainbow trout (Biga et al. 2004), whereas no effect has been reported in common carp (Vong et al. 2003).

The present study is the first to show that IGF-I occurs in the bony fish pituitary. IGF-I has been observed in both the neuro- and adenopituitary. In the posterior part, neurosecretory axons containing IGF-I immunoreactivity appear around $17 \mathrm{DPF}$, whereas no IGF-I mRNA is detected at this stage. The likely source of IGF-I in the neuropituitary is the neuronal perikarya that lie within the hypothalamus and that exhibit IGF-I immunoreactivity. In the adenopituitary, IGF-I mRNA is first detected at 20 DPF. IGF-I immunoreactivity and mRNA in endocrine cells are present throughout development. To date, IGF-I immunoreactivity has only been localized in the anterior pituitary in the frog Xenopus laevis in which it occurs in co-existence with prolactin (David et al. 2000). Because IGF-I-binding sites have also been found in X. laevis anterior pituitary, IGF-I from the prolactin cells has been postulated to regulate $\mathrm{GH}$ in a paracrine manner (David et al. 2000). Whether this hypothesis also applies to bony fish remains to be clarified, as does the type of endocrine cells producing IGF-I.

At 5 DPF, IGF-I has been detected in cells of the epidermis of tilapia. The number of IGF-I-producing epidermal cells first increases with age, reaching its highest level around 19-29 DPF. In older larvae and adults, some superficial and basal epidermal cells exhibit IGF-I immunoreactivity or IGF-I mRNA. In developing skin of shi drum, IGF-1R immunoreactivity is detectable even at hatching (Radaelli et al. 2003). The early appearance of both IGF-I and its receptor suggests an important auto/ paracrine function of IGF-I in skin development. Because some IGF-I producing cells still occur in the basal and superficial layers in juvenile and adult tilapia and as high levels of IGF receptor mRNA have been found in adult gilthead seabream skin (Perrot et al. 1999), local IGF-I in fish skin might play a role in later life. Skin IGF-I might be involved in repair mechanisms and wound healing, as has been proposed in mammals (Edmondson et al. 2003).

In summary, the expression of IGF-I is more pronounced during ontogeny than in juvenile and adult life in the parenchymal cells of most of the organs investigated, such as epithelial cells of the gastro-intestinal tract, acinar cells of the exocrine pancreas, skeletal muscle cells, cardiomyocytes, renal tubular cells, neurones of the central and peripheral nervous system and skin cells. These results suggest a high functional impact of local IGF-I in early fish growth, metabolism and organogenesis by auto/paracrine means of regulation. Whether IGF-I expression in the early development of fish is regulated by $\mathrm{GH}$ remains to be clarified (Perrot et al. 1999; Deane et al. 2003), although low levels of GH mRNA have been detected as early as gastrulation in rainbow trout and intermediate amounts of
GH mRNA have been observed in early cleavage-stage embryos (Yang et al. 1999).

\section{References}

Ayson FG, Jesus EG de, Moriyama S, Hyodo S, Funkenstein B, Gertler A, Kawauchi H (2002) Differential expression of insulin-like growth factor I and II mRNAs during embryogenesis and early larval development in rabbitfish, Siganus guttatus. Gen Comp Endocrinol 126:165-174

Baños N, Moon TW, Castejon C, Gutiérrez J, Navarro I (1997) Insulin and insulin-like growth factor-I (IGF-I) binding in fish red muscle: regulation by high insulin levels. Regul Pept 68:181-187

Baroiller JF, Desprez D, Carteret Y, Tacon P, Hoareau MC, Mélard C, Jalabert B (1997) Influence of environmental and social factors on the reproductive efficiency in three tilapia species, Oreochromis niloticus, O. aureus and the red tilapia (Red Florida strains). In: Fitzsimmons K (ed) Proceedings of the Fourth International Symposium on Tilapia in Aquaculture, 9-12 November 1997, Orlando, Fla., USA. Northeast Regional Agriculture Engineering Service, New York, pp 238-252

Bern HA, McCormick SD, Kelley KM, Gray ES, Nishioka RS, Madsen SS, Tsai PL (1991) Insulin-like growth factors "under water": role in growth and function of fish and other poikilothermic vertebrates. In: Spencer EM (ed) Modern concepts of insulin-like growth factors. Elsevier, New York, pp 85-96

Berwert L, Segner H, Reinecke M (1995) Ontogeny of IGF-1 and the classical islet hormones in the turbot, Scophthalmus maximus. Peptides 16:113-122

Biga PR, Schelling GT, Hardy RW, Cain KD, Overturf K, Ott TL (2004) The effects of recombinant bovine somatotropin (rbST) on tissue IGF-I, IGF-I receptor, and GH mRNA levels in rainbow trout, Oncorhynchus mykiss. Gen Comp Endocrinol 135:324-323

Caelers A, Schmid AC, Hrusovsky A, Reinecke M (2003) Insulinlike growth factor II mRNA is expressed in neurones of the brain of the bony fish Oreochromis mossambicus, the tilapia. Eur J Neurosci 18:355-363

Caelers A, Berishvili G, Meli ML, Eppler E, Reinecke M (2004) Establishment of a real-time RT-PCR for the determination of absolute amounts of IGF-I and IGF-II gene expression in liver and extrahepatic sites of the tilapia. Gen Comp Endocrinol 137:196-204

Castillo J, Codina M, Martinez ML, Navarro I, Gutiérrez J (2004) Metabolic and mitogenic effects of IGF-I and insulin on muscle cells of rainbow trout. Am J Physiol Regul Integr Comp Physiol 286:R935-R941

Cheng CM, Cohen M, Tseng V, Bondy CA (2001) Endogenous IGF1 enhances cell survival in the postnatal dentate gyrus. J Neurosci Res 64:341-347

Chourrout D, Itskovich J (1983) Three manipulations permitted by artificial insemination in tilapia: induced diploid gynogenesis, production of all triploid population and intergeneric hybridisation. In: Fishelson L, Yaron Z (eds) International Symposium on Tilapia in Aquaculture, Nazareth, Israel. Tel Aviv University, Tel Aviv, pp 246-255

David I, Bosshard R, Kloas W, Reinecke M (2000) Insulin-like growth factor I in the anterior pituitary of the clawed frog Xenopus laevis: immunocytochemical and autoradiographic indication for a paracrine action and corelease with prolactin. J Neuroendocrinol 12:415-420

Deane EE, Kelly SP, Collins PM, Woo NY (2003) Larval development of silver sea bream (Sparus sarba): ontogeny of RNA-DNA ratio, GH, IGF-I, and $\mathrm{Na}(+)-\mathrm{K}(+)$-ATPase. Mar Biotechnol (NY) 5:79-91

Duan C (1998) Nutritional and developmental regulation of insulinlike growth factors in fish. J Nutr 128:306S-314S 
Duan C, Hirano T (1992) Effects of insulin-like growth factor-I and insulin on the in-vitro uptake of sulphate by eel branchial cartilage: evidence for the presence of independent hepatic and pancreatic sulphation factors. J Endocrinol 133:211-219

Duan C, Duguay SJ, Plisetskaya EM (1993) Insulin-like growth factor I (IGF-I) mRNA expression in coho salmon, Oncorhynchus kisutch: tissue distribution and effects of growth hormone/prolactin family protein. Fish Physiol Biochem 11:371-379

Duan C, Plisetskaya EM, Dickhoff WW (1995) Expression of insulinlike growth factor I in normally and abnormally developing coho salmon (Oncorhynchus kisutch). Endocrinology 136:446-452

Duan CM, Inui Y (1990) Effects of recombinant eel growth hormone on the uptake of [35S]sulfate by ceratobranchial cartilages of the Japanese eel, Anguilla japonica. Gen Comp Endocrinol 79:320-325

Duguay SJ, Swanson P, Dickhoff WW (1994) Differential expression and hormonal regulation of alternatively spliced IGF-I mRNA transcripts in salmon. J Mol Endocrinol 12:25-37

Duguay SJ, Lai-Zhang J, Steiner DF, Funkenstein B, Chan SJ (1996) Developmental and tissue-regulated expression of IGF-I and IGF-II mRNAs in Sparus aurata. J Mol Endocrinol $16: 123-132$

Edmondson SR, Thumiger SP, Werther GA, Wraight CJ (2003) Epidermal homeostasis: the role of the growth hormone and insulin-like growth factor systems. Endocr Rev 24:737-764

Fryer JN (1979) A radioreceptor assay for purified teleost growth hormone. Gen Comp Endocrinol 39:123-130

Funkenstein B, Silbergeld A, Cavari B, Laron Z (1989) Growth hormone increases plasma levels of insulin-like growth factor (IGF-I) in a teleost, the gilthead seabream (Sparus aurata). J Endocrinol 120:R19-R21

Funkenstein B, Almuly R, Chan SJ (1997) Localization of IGF-I and IGF-I receptor mRNA in Sparus aurata larvae. Gen Comp Endocrinol 107:291-303

Greene MW, Chen TT (1997) Temporal expression pattern of insulin-like growth factor mRNA during embryonic development in a teleost, rainbow trout (Onchorhynchus mykiss). Mol Mar Biol Biotechnol 6:144-151

Greene MW, Chen TT (1999) Quantitation of IGF-I, IGF-II, and multiple insulin receptor family member messenger RNAs during embryonic development in rainbow trout. Mol Reprod Dev 54:348-356

Gutiérrez J, Parrizas M, Maestro MA, Navarro I, Plisetskaya EM (1995) Insulin and IGF-I binding and tyrosine kinase activity in fish heart. J Endocrinol 146:35-44

Hansson H-A, Nilsson A, Isgaard J, Billig H, Isaksson O, Skottner A, Andersson IK, Rozell B (1988) Immunohistochemical localization of insulin-like growth factor I in the adult rat. Histochemistry 89:403-410

Hirschberg R (1996) Insulin-like growth factor I in the kidney. Miner Electrolyte Metab 22:128-132

Howarth GS (2003) Insulin-like growth factor-I and the gastrointestinal system: therapeutic indications and safety implications. J Nutr 133:2109-2112

Inoue K, Iwatani H, Takei Y (2003) Growth hormone and insulinlike growth factor I of a euryhaline fish Cottus kazika: cDNA cloning and expression after seawater acclimation. Gen Comp Endocrinol 131:77-84

Jevdjovic T, Maake C, Eppler E, Zoidis E, Reinecke M, Zapf J (2004) Effects of insulin-like growth factor-I treatment on the endocrine pancreas of hypophysectomized rats: comparison with growth hormone replacement. Eur J Endocrinol 151:1-10

Kakizawa S, Yamada K, Iino M, Watanabe M, Kano M (2003) Effects of insulin-like growth factor I on climbing fibre synapse elimination during cerebellar development. Eur J Neurosci 17:545-554

Kelley KM, Gray ES, Siharath K, Nicoll CS, Bern HA (1993) Experimental diabetes mellitus in a teleost fish. II. Roles of insulin, growth hormone $(\mathrm{GH})$, insulin-like growth factor-I, and hepatic GH receptors in diabetic growth inhibition in the goby, Gillichthys mirabilis. Endocrinology 132:2696-2702
Koppang EO, Thomas GA, Ronningen K, Press CML (1998) Expression of insulin-like growth factor-I in the gastrointestinal tract of Atlantic salmon (Salmo salar L.). Fish Physiol Biochem $18: 167-175$

Leahy JL, Vandekerkhove KM (1990) Insulin-like growth factor-I at physiological concentrations is a potent inhibitor of insulin secretion. Endocrinology 126:1593-1598

Leibush B, Parrizas M, Navarro I, Lappova Y, Maestro MA, Encinas M, Plisetskaya EM, Gutiérrez J (1996) Insulin and insulin-like growth factor-I receptors in fish brain. Peptides 61:155-161

Loffing-Cueni D, Schmid AC, Graf H, Reinecke M (1998) IGF-I in the bony fish Cottus scorpius: cDNA, expression and differential localization in brain and islets. Mol Cell Endocrinol 141:187-194

Madsen SS, Bern HA (1993) In-vitro effects of insulin-like growth factor-I on gill Na,K(+)-ATPase in coho salmon, Oncorhynchus kisutch. J Endocrinol 138:23-30

Madsen SS, Jensen MK, Nhr J, Kristiansen K (1995) Expression of $\mathrm{Na}(+)-\mathrm{K}(+)$-ATPase in the brown trout, Salmo trutta: in vivo modulation by hormones and seawater. Am J Physiol 269: R1339-R1345

Mancera JM, McCormick SD (1998) Evidence for growth hormone/ insulin-like growth factor I axis regulation of seawater acclimation in the euryhaline teleost Fundulus heteroclitus. Gen Comp Endocrinol 111:103-112

McCormick SD (1996) Effects of growth hormone and insulin-like growth factor I on salinity tolerance and gill $\mathrm{Na}, \mathrm{K}+$-ATPase in Atlantic salmon (Salmo salar): interaction with cortisol. Gen Comp Endocrinol 101:3-11

McCormick SD, Tsai PI, Kelley KM, Nishioka RS, Bern HA (1992) Hormonal control of sulfate uptake by branchial cartilage of coho salmon: role of IGF-I. J Exp Zool 262:166-171

Mendez E, Smith A, Figueiredo-Garutti ML, Planas JV, Navarro I, Gutiérrez J (2001) Receptors for insulin-like growth factor-I (IGF-I) predominate over insulin receptors in skeletal muscle throughout the life cycle of brown trout, Salmo trutta. Gen Comp Endocrinol 122:148-157

Moon TW, Castejon C, Baños N, Maestro MA, Plisetskaya EM, Gutiérrez J, Navarro I (1996) Insulin and IGF-I binding in isolated trout cardiomyocytes. Gen Comp Endocrinol 103:264-272

Moriyama S (1995) Increased plasma insulin-like growth factor-I (IGF-I) following oral and intraperitoneal administration of growth hormone to rainbow trout, Oncorhynchus mykiss. Growth Regul 5:164-167

Moriyama S, Ayson FG, Kawauchi H (2000) Growth regulation by insulin-like growth factor-I in fish. Biosci Biotechnol Biochem 64:1553-1562

Ng TB, Leung TC, Cheng CHK, Woo NYS (1992) Growth hormone binding sites in tilapia (Oreochromis mossambicus) liver. Gen Comp Endocrinol 86:111-118

Niblock MM, Brunso-Bechtold JK, Riddle DR (2000) Insulin-like growth factor I stimulates dendritic growth in primary somatosensory cortex. J Neurosci 20:4165-4176

Niu PD, Pérez-Sanchez J, Le Bail PY (1993) Development of a protein binding assay for teleost insulin-like growth factor (IGF-like): relationship between growth hormone $(\mathrm{GH})$ and IGF-like in the blood of rainbow trout (Oncorrhynchus mykiss). Fish Physiol Biochem 11:381-391

Perrot V, Moiseeva EB, Gozes Y, Chan SJ, Ingleton, P, Funkenstein B (1999) Ontogeny of the insulin-like growth factor system (IGF-I, IGF-II, and IGF-1R) in gilthead seabream (Sparus aurata): expression and cellular localization. Gen Comp Endocrinol 116:445-460

Pierce AL, Fukada H, Dickhoff WW (2005) Metabolic hormones modulate the effect of growth hormone $(\mathrm{GH})$ on insulin-like growth factor-I (IGF-I) mRNA level in primary culture of salmon hepatocytes. J Endocrinol 184:341-349

Plisetskaya EM (1998) Some of my not so favorite things about insulin and insulin-like growth factors in fish. Comp Biochem Physiol [B] 121:3-11 
Plisetskaya EM, Bondareva VM, Duan C, Duguay SJ (1993) Does salmon brain produce insulin? Gen Comp Endocrinol 91:74-80

Pozios KC, Ding J, Degger B, Upton Z, Duan C (2001) IGFs stimulate zebrafish cell proliferation by activating MAP kinase and PI3-kinase-signaling pathways. Am J Physiol Regul Integr Comp Physiol 280:R1230-R1239

Radaelli G, Domeneghini C, Arrighi S, Bosi G, Patruno M, Funkenstein B (2003) Localization of IGF-I, IGF-I receptor, and IGFBP-2 in developing Umbrina cirrosa (Pisces: Osteichthyes). Gen Comp Endocrinol 130:232-244

Reinecke M, Collet C (1998) The phylogeny of the insulin-like growth factors. Int Rev Cytol 183:1-94

Reinecke M, Maake C, Falkmer S, Sara VR (1993) The branching of insulin-like growth factor 1 and insulin: an immunohistochemical analysis during phylogeny. Regul Pept 48:65-76

Reinecke M, Schmid A, Ermatinger R, Loffing-Cueni D (1997) Insulin-like growth factor I in the teleost Oreochromis mossambicus, the tilapia: gene sequence, tissue expression, and cellular localization. Endocrinology 138:3613-3619

Reinecke M, Schmid AC, Heyberger-Meyer B, Hunziker EB, Zapf J (2000) Effect of growth hormone and insulin-like growth factor I (IGF-I) on the expression of IGF-I mRNA and peptide in rat tibial growth plate and articular chondrocytes in vivo. Endocrinology 141:2847-2853

Reinecke M, Björnsson BT, Dickhoff WW, McCormick SD, Navarro I, Power DM, Gutiérrez J (2005) Growth hormone and insulin-like growth factors in fish: where we are and where to go. Gen Comp Endocrinol 142:20-24

Richardson NA, Anderson AJ, Rimmer MA, Sara VR (1995) Localization of insulin-like growth factor-I immunoreactivity in larval and juvenile barramundi (Lates calcarifer). Gen Comp Endocrinol 100:282-292

Sakamoto T, Hirano T (1993) Expression of insulin-like growth factor I gene in osmoregulatory organs during seawater adaptation of the salmonid fish: possible mode of osmoregulatory action of growth hormone. Proc Natl Acad Sci USA 90:1912-1916

Schmid AC, Naf E, Kloas W, Reinecke M (1999) Insulin-like growth factor-I and -II in the ovary of a bony fish, Oreochromis mossambicus, the tilapia: in situ hybridisation, immunohistochemical localisation, Northern blot and cDNA sequences. Mol Cell Endocrinol 156:141-149

Schmid AC, Reinecke M, Kloas W (2000) Primary cultured hepatocytes of the bony fish, Oreochromis mossambicus, the tilapia: a valid tool for physiological studies on IGF-I expression in liver. J Endocrinol 166:265-273

Schober DA, Simmen FA, Hadsell DL, Baumrucker CR (1990) Perinatal expression of type I IGF receptors in porcine small intestine. Endocrinology 126:1125-1132

Segner H, Storch V, Reinecke M, Kloas W, Hanke W (1994) The development of functional digestive and metabolic organs in turbot, Scophthalmus maximus. Mar Biol 119:471-486
Seidelin M, Madsen SS (1999) Endocrine control of Na,K+-ATPase and chloride cell development in brown trout (Salmo trutta): interaction of insulin-like growth factor-I with prolactin and growth hormone. J Endocrinol 162:127-135

Seidelin M, Madsen SS, Byrialsen A, Kristiansen K (1999) Effects of insulin-like growth factor-I and cortisol on $\mathrm{Na}, \mathrm{K}+$-ATPase expression in osmoregulatory tissues of brown trout (Salmo trutta). Gen Comp Endocrinol 113:331-342

Shamblott MJ, Chen TT (1993) Age-related and tissue-specific levels of five forms of insulin-like growth factor mRNA in a teleost. Mol Mar Biol Biotechnol 2:351-361

Shamblott MJ, Cheng CM, Bolt D, Chen TT (1995) Appearance of insulin-like growth factor mRNA in the liver and pyloric ceca of a teleost in response to exogenous growth hormone. Proc Natl Acad Sci USA 92:6943-6946

Shepherd BS, Sakamoto T, Nishioka RS, Richman NH, Mori I, Madsen SS, Chen TT, Hirano T, Bern HA, Grau EG (1997) Somatotropic actions of the homologous growth hormone and prolactins in the euryhaline teleost, the tilapia, Oreochromis mossambicus. Proc Natl Acad Sci USA 94:2068-2072

Shved N, Berishvili G, D'Cotta H, Baroiller JF, Eppler E, Segner H, Reinecke M (2005) A survey on the expression of IGF-I in the early developing bony fish with special emphasis on the tilapia, Oreochromis niloticus. Ann N Y Acad Sci 1040:469-471

Smith A, Chan SJ, Gutierrez J (2005) Autoradiographic and immunohistochemical localization of insulin-like growth factor-I receptor binding sites in brain of the brown trout, Salmo trutta. Gen Comp Endocrinol 141:203-213

Steeb CB, Trahair JF, Tomas FM, Read LC (1994) Prolonged administration of IGF peptides enhances growth of gastrointestinal tissues in normal rats. Am J Physiol 266:G1090-G1098

Tsai PI, Madsen SS, McCormick SD, Bern HA (1994) Endocrine control of cartilage in coho salmon: $\mathrm{GH}$ influence in vivo on the response to IGF-I in vitro. Zool Sci 11:299-303

Van Schravendijk CF, Heylen L, Van den Brande JL, Pipeleers DG (1990) Direct effect of insulin and insulin-like growth factor-I on the secretory activity of rat pancreatic beta cells. Diabetologia 33:649-653

Vong QP, Chan KM, Cheng CH (2003) Quantification of common carp (Cyprinus carpio) IGF-I and IGF-II mRNA by real-time PCR: differential regulation of expression by GH. J Endocrinol 178:513-521

Wood AW, Duan C, Bern HA (2005) Insulin-like growth factor signaling in fish. Int Rev Cytol 243:215-285

Yang BY, Greene M, Chen TT (1999) Early embryonic expression of the growth hormone family protein genes in the developing rainbow trout, Oncorhynchus mykiss. Mol Reprod Dev 53:127-134

Zhou X, Herman JP, Paden CM (1999) Evidence that IGF-I acts as an autocrine/paracrine growth factor in the magnocellular neurosecretory system: neuronal synthesis and induction of axonal sprouting. Exp Neurol 159:419-432 